\title{
Mobile mud layer underneath the desiccated maar lake of Rincón de Parangueo and insights into its microbial fingerprints
}

\author{
Janet Sánchez-Sánchez ${ }^{1}$, Mariano Cerca ${ }^{2, *}$, Rocío J Alcántara-Hernández ${ }^{3}$, \\ José Jorge Aranda-Gómez ${ }^{2}$, Dora Carreón-Freyre ${ }^{2}$, Carlos Lozano-Flores ${ }^{4}$, \\ Israel Muñoz-Velasco ${ }^{5}$, Gilles Levresse ${ }^{2}$, and Alfredo Varela-Echavarría ${ }^{4}$
}

\author{
${ }^{1}$ Posgrado en Ciencias de la Tierra, Centro de Geociencias, Universidad Nacional Autónoma de México, \\ Blvd. Juriquilla, 3001, 76230, Juriquilla, Querétaro, Mexico. \\ ${ }^{2}$ Centro de Geociencias, Universidad Nacional Autónoma de México, \\ Blvd. Juriquilla, 3001, 76230, Juriquilla, Querétaro, Mexico. \\ ${ }^{3}$ Instituto de Geología, Universidad Nacional Autónoma de México, Ciudad Universitaria, \\ Av. Universidad 3000, Del. Coyoacán, 04510, Mexico City, Mexico. \\ ${ }^{4}$ Departamento de Biología del Desarrollo y Neurofisiología, Instituto de Neurobiología, \\ Universidad Nacional Autónoma de México, Querétaro, Mexico. \\ ${ }^{5}$ Facultad de Ciencias, Universidad Nacional Autónoma de México, \\ Apdo. Postal 70-407, Cd. Universitaria, 04510, Mexico City, Mexico. \\ *mcerca@geociencias.unam.mx, ORCID 0000-0002-9264-4553
}

\begin{abstract}
We surveyed a subsurface layer of saturated mobile mud and its microbial fingerprints below the desiccated bottom of a maar lake at Rincón de Parangueo (RP), Mexico. A multi-scale approach was followed using geological fieldwork, coring of the sediments, ground penetrating radar survey, physico-chemical characterization including X-ray diffraction and scanning electron microscope, and high-throughput DNA sequencing methods. The mobile mud is an organic-rich silty clay, with high values of alkalinity, volumetric water content and conductivity. Mud mobility has been attributed to overpressure caused by disequilibrium compaction of sediments related to active subsidence and pore overpressure produced by an input of groundwater and gas content in the sediments and resulted in a diverse set of structures related to mud tectonics such as injection domes and fluid seeps through fractures. Extraction and sequencing of sedimentary environmental DNA in the mud layer were performed for Bacteria and Archaea. Despite the small number of samples obtained, the microbial fingerprint from the sedimentary environmental DNA at subsurface shares similarities with the microbial communities identified on the crater surface. Additionally, we identify the DNA of specific methanogenic microorganisms in the mud, such as Bathyarchaeia, Methanomassiliicoccales, and Methanobacteriales, and we speculate on their probable role in gas production and pore overpressure in the mud layer. The underground mud at Rincón de Parangueo represents a geologically dynamic environment with conditions that are favorable for the thriving of microbial communities.
\end{abstract}

Key words: saturated mud; microbiology; mud injection domes; maar cráter; lake.

\section{RESUMEN}

En este trabajo examinamos una capa subsuperficial de lodo saturado móvil y su huella microbiana (sedimentary environmental DNA) por debajo del fondo desecado del lago maar en Rincón de Parangueo (RP), México. Se siguió un enfoque de múltiples escalas, se integró trabajo de campo geológico, extracción de núcleos de sedimentos cercanos a la superficie, prospección por radar de penetración terrestre, caracterización fisicoquímica incluida la difracción de rayos $X$ y microscopio electrónico de barrido y métodos de secuenciación de ADN de alto rendimiento. El lodo móvil está compuesto de arcilla limosa rica en materia orgánica total, con altos valores de alcalinidad, contenido volumétrico de agua y conductividad. La movilidad del lodo se atribuye a la sobrepresión causada por la compactación desequilibrada de los sedimentos, relacionada con la subsidencia activa en el cráter, y la sobrepresión de poro producida por una entrada de agua subterránea ygas en los sedimentos, lo que da como resultado un conjunto diverso de estructuras relacionadas con la tectónica de lodo, como domos de inyección de lodo y filtraciones de fluido a través de fracturas. La extracción y secuenciación de ADN ambiental en la capa de lodo se realizó para Bacteria y Archaea. A pesar de contar con un número pequeño de muestras de sedimentos, la huella microbiana obtenida en el subsuelo comparte similitudes con las secuencias identificadas en la superficie del cráter. Adicionalmente, en el lodo reportamos la presencia de microorganismos metanogénicos, tales como Bathyarchaeia, Methanomassiliicoccales y Methanobacteriales, $y$ especulamos sobre su probable papel en la producción de gas y la sobrepresión del fluido de poro en la capa de lodo. El lodo subterráneo en Rincón de Parangueo representa un ambiente dinámico con condiciones favorables para el crecimiento de comunidades microbianas.

Palabras clave: lodo saturado; microbiología; domos de inyección de lodo; cráter maar; lago.

Sánchez-Sánchez, J., Cerca, M., Alcántara-Hernández, R.J, Aranda-Gómez, J.J., Carreón-Freyre, D., Lozano-Flores, C., Muñoz-Velasco, I., Levresse, G., VarelaEchavarría, A., 2021, Mobile mud layer underneath the desiccated maar lake of Rincón de Parangueo and insights into its microbial fingerprints: Revista Mexicana de Ciencias Geológicas, v. 38, núm. 3, p. 178-192. 


\section{INTRODUCTION}

The central part of the maar crater Rincón de Parangueo (RP) hosts a near-surface sedimentary sequence deposited in a closed lacustrine system (Kienel et al., 2009; Aranda-Gómez et al., 2013; 2017; Cerca et al., 2015; Domínguez-Vázquez et al., 2019; Sánchez-Sánchez et al., 2019). Sedimentary processes within the lacustrine system were active until the 1980's decade when overexploitation of the regional aquifer initiated a gradual decline of the water level and triggered active land subsidence (Aranda-Gómez et al., 2013; 2017). The morphology and sedimentation of the crater bottom have been profoundly affected since then by the rapid subsidence (ca. $\left.1 \mathrm{~m} \mathrm{year}^{-1}\right)$ and the large set of semicircular faults and fractures with throws mainly toward the center of the crater, forming a $15 \mathrm{~m}$ high topographic scarp (RochaTreviño, 2015; Aranda-Gómez et al., 2017). Nowadays, most of the crater surface is characterized by a dry carbonate plain, and only small residual brine ponds are present in the depocenter of the crater. Brine ponds are fed either by meteoric water during the rainy season and/ or by a local perched aquifer inside the crater (Aranda-Gómez et al., 2013), and/or by hydraulic connection with the regional aquifer favored by the fragmentation of the host rock during the volcanic eruption (Aranda-Gómez et al., 2013; Cerca et al., 2015; Sánchez-Sánchez et al., 2019). Despite the intense lake desiccation in this semiarid region, groundwater remains an important water contributor and the water table is maintained $1.2 \mathrm{~m}$ below the dry sedimentary cover. These abrupt changes in the environmental conditions allowed the presence, near the surface, of saturated mud that lost its layering structure and showed widespread evidence of mobilization and fluid migration manifested on the surface sediments. Structures observed include mud injection domes, brine pools, and gas seeps such as $\mathrm{CO}_{2}$ and $\mathrm{CH}_{4}$ (e.g., ArandaGómez et al., 2017; Paz et al., 2020). Paz et al. (2020) suggested that the $\mathrm{CH}_{4}$ emanating from the maar bottom has a biogenic origin. Through time the RP lacustrine system sustained the presence of microbial communities in an extreme environment (Levresse et al., 2014; Chacón et al., 2018; Sánchez-Sánchez et al., 2019; Ibarra-Sánchez et al., 2020). Sánchez-Sánchez et al. (2019) characterized the microbial component (Bacteria, Eukarya, and Archaea) in endolithic mats of calcareous sediments, and microbial mats and free-living microorganisms in the soda ponds in the crater. The phylotypes identified were related to the extreme environmental physicochemical characteristics (e.g., alkalinity and salinity). The bacterial and archaeal community from a sediment layer $(0-20 \mathrm{~cm})$ along a central crater transect were also characterized by Ibarra-Sánchez et al. (2020). Both analyzes determined the presence of phylotypes including Cyanobacteria, Firmicutes, Proteobacteria, Bacteroidota, Actinobacteriota, Crenarchaeota and Euryarchaeota. However, our understanding of the taxonomic compilation of lacustrine communities in RP is presently limited to the crater surface. Saturated mud physicochemical and geological characteristics might control microbial populations on the subsurface. Gas producing microorganisms such as methanogenic Archaea might be present in the saturated mud providing a biological source for the methane observed on the surface. In this work, we detail the characteristics of the highly mobile and saturated subsurface muddy layer present in the area and the nature of the sedimentary environmental DNA recovered, based on a multi-scale approach involving geophysical datasets acquired by Ground Penetrating Radar (GPR), sediment physicochemical characterization, and microbial analyses by high throughput DNA sequencing methods.

\section{Geological setting}

Rincón de Parangueo (RP) is a relatively small Quaternary maar, a volcanic crater with a diameter of around $1.3 \mathrm{~km}$, in the Michoacán-
Guanajuato Volcanic Field at the central part of the Trans-Mexican Volcanic Belt (Figure 1a). The geology and stratigraphy of the RP maar and its surroundings have been previously presented by Aranda-Gómez et al. $(2013 ; 2014 ; 2017)$. Here, we summarize some of the key points to give an oversight of the geological setting.

The Plio-Quaternary Michoacán - Guanajuato Monogenetic Volcanic Field (MGMVF), composed of more than 200 scoria cones, is located in the central part of the Trans-Mexican Volcanic Belt (TMVB). The northern part of the MGMVF is formed by continental shield volcanoes, scoria cones, and maars. RP maar is part of a volcanic complex (Valle de Santiago Volcanic Field; VSVF) formed by a continental lava shield, four maar-type volcanoes, and a lava dome, located near the town of Valle de Santiago (Aranda-Gómez et al., 2014). RP represents the youngest eruption reported so far in the area, with a maximum eruption age of $137 \pm 89 \mathrm{Ky}$ (Aranda-Gómez et al., 2017).

The precise onset time of the fine-grained, hydromagnesite- and organic-rich sedimentation in the RP lacustrine system is unknown but some constraints have been proposed. For instance, recent radiocarbon dating indicates an extrapolated age of approximately 21,000 years for the sediments collected at the base of a $14 \mathrm{~m}$ depth core collected in the center of maar (Domínguez-Vázquez et al., 2019). Other available constraints on core samples suggest that the laminated sediments from the central part of the crater, collected at 60 to $70 \mathrm{~cm}$ in depth, record a time-lapse between AD 1839-1943 (Kienel et al., 2009), and a wood nucleus on which a microbialite precipitated yielded $a{ }^{14} \mathrm{C}$ age of $\mathrm{AD}$ $1465 \pm 33$ (Levresse et al., 2014).

The sediments, exposed exceptionally by the lake desiccation, display a simple concentric carbonate facies distribution in RP (Figure 1a) (Aranda-Gómez et al., 2017; Sánchez-Sánchez et al., 2019). The platform bench is a nearly flat or gently inclined plane with a sedimentary sequence characterized by the presence of abundant oncolites. Between the sublittoral and slope zones of the former lake there is a conspicuous annular alignment of domical biohermal thrombolites, coinciding with the present-day main annular fault scarp related to subsidence. The former slope at the lake's bottom is now a steep zone where tilted blocks bounded by tensional joints and high angle normal and reverse faults are observed. The pelagic zone of the lake basin covers most of the lakebed area. This innermost zone has a near-surface record of thinly nearly horizontally laminated sediments, formed by organic-rich and detritic-rich varves (Figure 1b). A section reported by Kienel et al. (2009) consisted of $8 \mathrm{~cm}$ diameter tubes in two cores, of which MXRP3-1 of around $106 \mathrm{~cm}$ in length records a continuous sedimentation disrupted in the upper $50 \mathrm{~cm}$ by mud breccia, associated with the more recent subsidence period. In these randomly oriented chaotic deposits, each clast keeps its own sedimentary laminae (Aranda-Gómez et al., 2013;2017) as depicted in Figures $1 \mathrm{~b}$ and $2 \mathrm{a}, 2 \mathrm{~b}$. The underlying layered sediments are composed of a thin lamina of tan-colored carbonaceous micritic mud and siltyclayey sediments with a larger organic matter content (Figures 2b, 2c). Some silt and fine sand layers are also interbedded in the sequence (Kienel et al., 2009). In addition, these authors reported the presence of "black intercalated layers" composed of silt and fine sand where the presence of green-yellow and brown-red organic-rich sludges were observed in the form of sheets or as disseminated materials, suggesting the possibility that organic matter is a local product of microorganisms. Below the laminated sediments (approx. $120 \mathrm{~cm}$ ) there is an abrupt change in sediment properties, and we report here for the first time the presence of a highly compressible, massive, and saturated, organic, mobile, and not-laminated mud, their properties, and its microbial fingerprint. We discuss the implications that this mud layer has on the present-day morphology of the crater. 


\section{MATERIALS AND METHODS}

\section{Stratigraphy of the crater sediments and mud tectonics}

Field work included the verification of evidence for the mud mobility. This included mapping the location, distribution and size of mud domes and other seepage features observed on the surface of the nearly dry lake inside the maar crater (Figure 3). For this study, stratigraphic logs obtained by coring down to $4 \mathrm{~m}$ depth in the sedimentary succession (Sediment samples in Figure la and 3a) were described. Two sediment samples from the cores, collected in the central part of the crater, were selected to determine the main physicochemical properties in a saturated paste prepared using distilled water (NOM-021RECNAT-2000): gravimetric water content, organic matter content, $\mathrm{pH}$ and, electric conductivity (EC). The determinations were made at the Laboratorio de Mecánica de Geosistemas (LAMG), Universidad Nacional Autónoma de México (UNAM). Sampling was difficult by

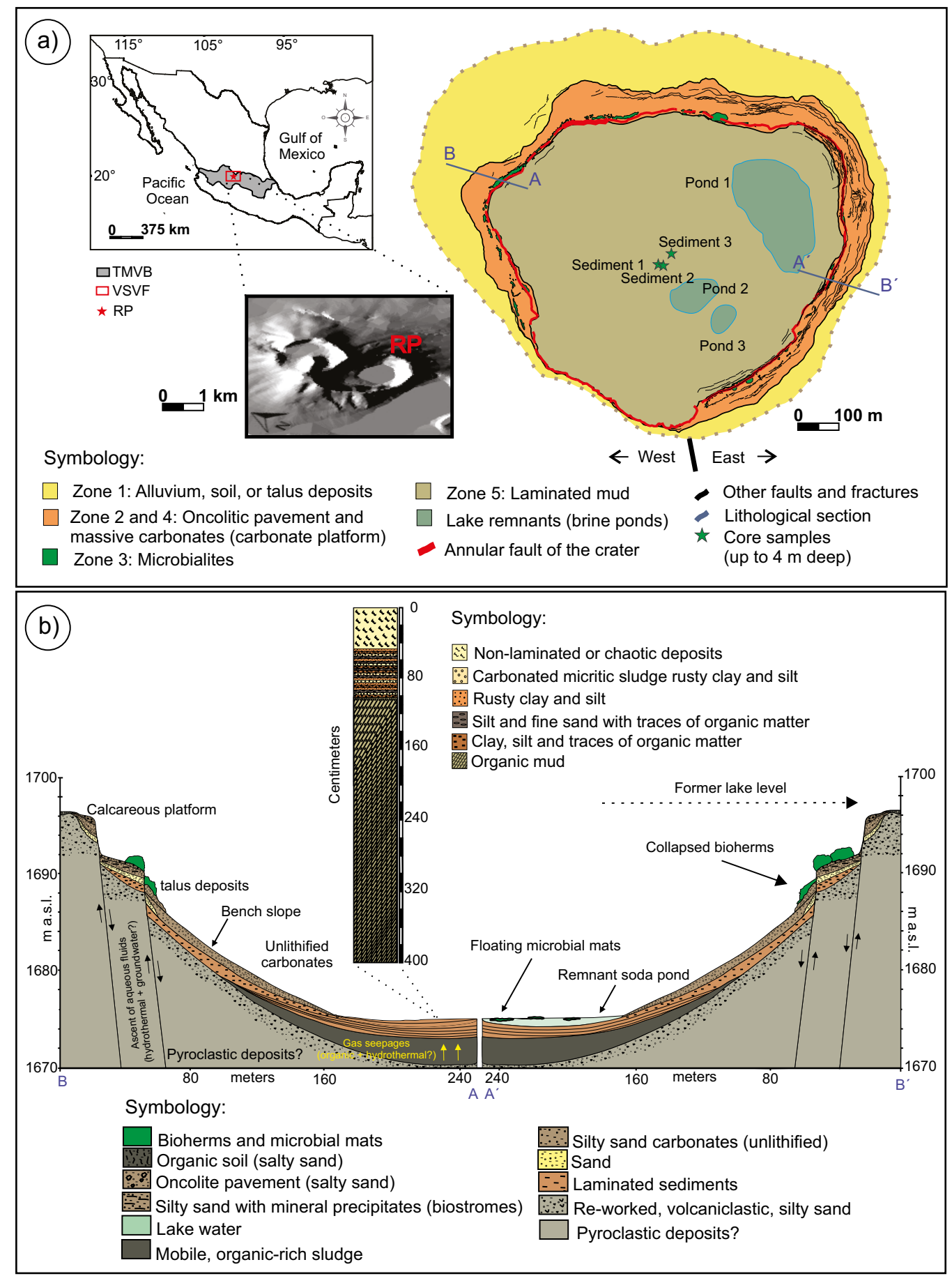

Figure. 1. a. Geographic location of the maar Rincón de Parangueo (RP), at the north-central part of the Trans Mexican Volcanic Belt (TMVB). The digital elevation map shows the morphology of RP and neighboring volcanoes. b. Generalized stratigraphic succession found at the sites where the Sediment 1 , Sediment 2 , and Sediment 3 cores were collected. Diagrammatic cross sections AB and $A^{\prime} B^{\prime}$. Note that the central portion of the former lake is omitted. 

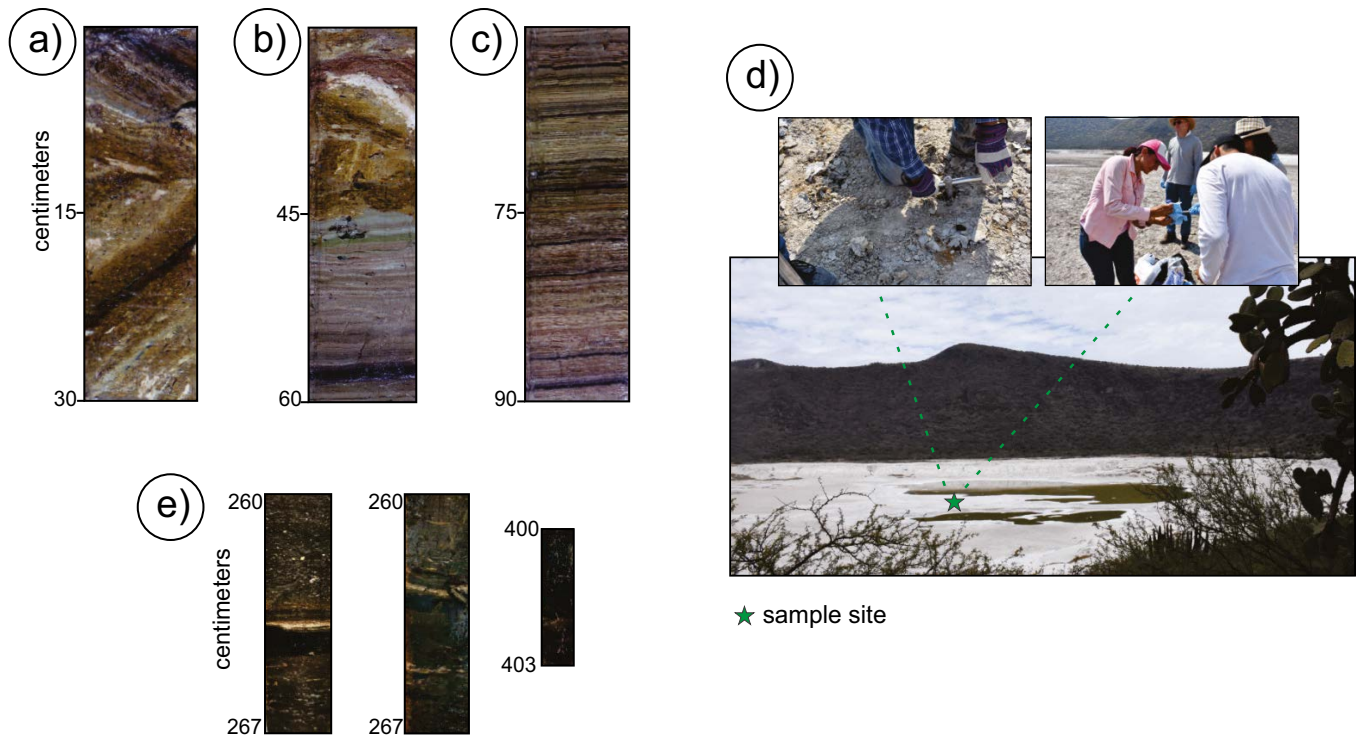

$\star$ sample site

Figure. 2. Photographs a - $\mathrm{c}$ show the lithological and structural characteristics preserved in a mud core, down to $0.9 \mathrm{~m}$ depth. a. The first $45 \mathrm{~cm}$ of the lake sediments are composed of a chaotic microbreccia made by randomly oriented, laminated mud fragments set in a massive, structureless matrix. $b$ and $c$. Laminated succession where individual lamina can be differentiated by color: the beige colored layers are composed of a carbonate sludge with micritic texture. The dark brown lamina consists of clay, silt, and traces of organic matter (after Kienel et al., 2009). Black intercalated laminae are composed of silt and fine sand where the presence of thin sludge lamina, rich green-yellow or brown-red organic matter was observed. d. Some aspects of the process of sediment sampling with a mechanical corer. e. Two representative mud samples which were found below the laminated sequence at $260-267 \mathrm{~cm}$ and $400-403 \mathrm{~cm}$, respectively. Recovery of deeper than $4 \mathrm{~m}$ mud samples is difficult because of the very low compaction of the saturated mud.

the instability of the mud surface and the impossibility of carrying a larger corer into the crater that is considered a protected natural park.

\section{Ground Penetrating Radar (GPR) survey}

GPR is a non-destructive geophysical prospecting technique that has been widely used for the identification of shallow subsurface geological structures corresponding to variations in the depositional environment, improving direct field observations. Changes in the radar wave propagation can be related to rock or sediment facies, changes involving variations in physical and mechanical properties such as grain size, density, compaction, the orientation of particles, the presence of faults and fractures, among others (Carreón-Freyre et al., 2003). GPR profiles were recorded along the central part of the former lake for assessing the structure of the sediment succession accumulated at the bottom of the RP volcanic crater. The GPR survey included two profiles with a $200 \mathrm{MHz}$ Antenna, each $\sim 1000 \mathrm{~m}$ long, continuously recorded using a tachometer calibrated to collect 40 traces per meter. The path of the profile was controlled with GPS and detailed land morphology was included by using a high-resolution topographic survey. The position of selected sites along the profiles allowed to properly incorporate the topographic changes (dots along profiles $\mathrm{A}-\mathrm{A}^{\prime}$ and $\mathrm{B}-\mathrm{B}^{\prime}$ in Figure $3)$. Both complete profiles were preliminary presented in Cerca $e t$ al. (2014). For this work, we have processed and reinterpreted the GPR data for enhancing visualization of the mud intrusions geometries and the disruption of the stratigraphy at the central part of the maar-lake.

\section{Geochemistry: major, minor, and trace element cations}

Water samples from the mud brine were obtained by vacuum filtering of saturated mud collected at depths up to 4 meters, and analyzed at the Laboratorio de Geoquímica Ambiental, Centro de Geociencias, UNAM. The analysis of major, minor, and trace element cations was performed according to the EPA 200.7 method (EPA, 2001). The analysis was made in an Optical Emission Spectrophotometry with Inductively Coupled Thermo iCAP 6500 Duo Plasma, using an internal yttrium standard of $1 \mathrm{ppm}$ to evaluate that the instrument's signal was within a $\pm 10 \%$ error range. The calibration standards were divided into two curves. The major ion curve was prepared from 1000 ppm Inorganic Ventures solutions in seven different concentrations. The calibration curve for minor and trace cations was prepared from a high purity standard (ICP-200-5). The correlation coefficients for the calibration curves were greater than 0.9990 , the recovery percentages were greater than $90 \%$, and were evaluated by means of laboratory control samples, prepared from certified standards of the high purity brand (QCS-26, standards Elemental mono and ICP-200-5).

\section{Anion Analysis}

Anion determination in groundwater obtained from the mud samples collected up to a $4 \mathrm{~m}$ depth was performed according to the EPA 300.1 method (Hautman and Munch, 1997), and analyzed at the Laboratorio de Geoquímica Ambiental of Centro de Geociencias, UNAM. The chemical analysis was performed using a Thermo-Dionex 1100 brand HPLC-IC with suppressor ASRS-Ultra 300 4-mm, column IonPac AS14A and electrochemical detector ED50. An 8.0 mM $1.0 \mathrm{mM}$ $\mathrm{Na}_{2} \mathrm{CO}_{3} / \mathrm{NaHCO}_{3}$ solution was used as the mobile phase to carry the sample at a flow rate of $1 \mathrm{ml} / \mathrm{min}$, with an injection volume of $50 \mu \mathrm{l}$. The preparation of the calibration curves was carried out with Inorganic Ventures IF-FAS-1A standards which consisted of seven concentrations, the control of the instrument drift was carried out by means of laboratory control samples prepared from a Seven Anion Standard of Dionex which was analyzed every 10 measurements. Both solutions used as reference standards have traceability to NIST. The correlation coefficient in the analytical curves used was greater than 0.9993 and the recovery rates of the control samples were greater than $90 \%$.

\section{$\mathrm{X}$-ray diffraction and scanning electron microscope observations}

Scanning electron microscope (SEM) observations were performed in millimeter-sized mud fragments mounted on an aluminum plate covered with carbon conductive adhesive tape. The analysis was made 


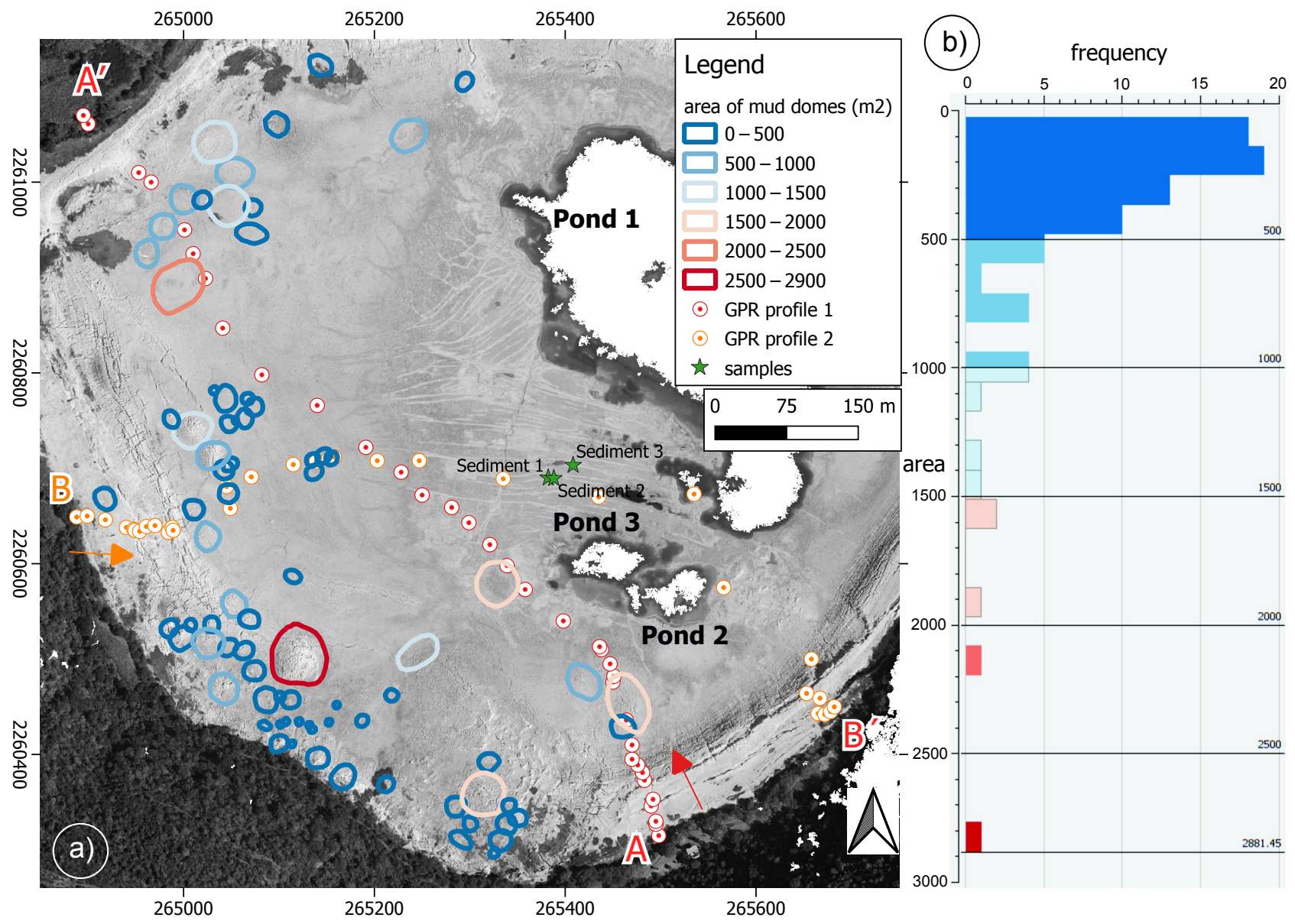

Figure. 3. a. Map showing 76 structures identified as injection mud domes on the surface in the western part of the crater, marked in different colors according to their size. White circles with dots in the center show the path followed to obtain the Ground Penetrating Radar profiles inside the former lakebed. White circles with orange dots are the locations measured used to construct the topography of profile A-A' and white circles with red dots for profile B-B ${ }^{\prime}$. b. Spatial size-distribution and dome-size frequency of the mud domes.

at the Laboratorio de Geoquímica de Fluidos Corticales at Centro de Geociencias, UNAM. Samples were studied in a HITACHI TM1000 SEM at $15 \mathrm{kV}$ with a backscattered detector. For X-ray diffraction (XRD), fractions of dry samples were disaggregated (to obtain fine grain $<0.002 \mathrm{~mm}$ ) in an agate mortar and were placed on aluminum plates. The samples were analyzed using a Miniflex Rigaku diffractometer using copper radiation $\mathrm{Ka} 1.5406 \AA$, between a $2 \theta$ angle of 5 to 80 degrees in steps of 0.02 degrees and $0.06 \mathrm{~s}$ for the measured spot. For crystalline phase identification, the PDF-2 database (Gates-Rector and Blanton, 2019) was used.

\section{Sampling for sedimentary environmental DNA}

The microbial fingerprint in the mud from sedimentary environmental DNA was characterized in aliquots taken from the mud samples collected in November 2017. Here, we use the term sedimentary-environmental DNA (sed-eDNA) for bulk DNA extracted from the mud layer as proposed by Ellegaard et al. (2020). Sampling was done with a mechanical corer at approximately $4 \mathrm{~m}$ depth below the desiccated bottom of the maar, in three different sampling stations in the central part of the crater (Figure 1a, 2d), named: Sediment 1 (20.430146 $\left.-101.248621^{\circ}\right)$, Sediment $2\left(20.430142,-101.248565^{\circ}\right)$, and Sediment $3\left(20.430269^{\circ},-101.248373^{\circ}\right)$. Mud aliquots were stored into $50 \mathrm{ml}$ sterile conical tubes (Corning Company, USA), preserved on ice during transport, and stored at $-20^{\circ} \mathrm{C}$ until processing.

\section{Nucleic acid extraction and data analysis}

Genomic DNA extraction was done from $30 \mathrm{~g}$ of mud following the sample preparation protocol reported by Bey et al. (2010) and following the instructions accompanying the PowerSoil extraction kit DNA Isolation (MoBio). Extraction was performed at the Lab A-03 of Departamento de Neurobiología del Desarrollo y Neurofisiología, Instituto de Neurobiología, UNAM. DNA was amplified by using the primers 28F (GAGTTTGATCNTGGCTCAG) and 519R (GTNTTACNGCGGCKGCTG) for Bacteria, and Arch517F (GCYTAAAGSRNCCGTAGC) and 909R (TTTCAGYCTTGCGRCCGTAC) for Archaea (Lay et al., 2013). Three samples (Sed 1, Sed 2 and Sed 3) were sent for Illumina MiSeq sequencing to RTL genomics company at Lubbock (TX, USA) (http:// rtlgenomics.com). The $16 \mathrm{~S}$ rRNA sequences were deposited in the NCBI database under the BioProject (PRJNA510628, BioSamples: SAMN14593312, SAMN14593313, SAMN14593314). Adapters and primers were removed using Trimmomatic v. 0.39 (Bolger et al., 2014). Analysis and processing of $16 \mathrm{~S}$ amplicons were made in R v. 3.6.3 (R core Team, 2020). Filtering and trimming by quality profiles, error estimation, dereplication process, merging of paired reads, remotion of chimerical sequences, and selection of amplicon sequence variants (ASVs) were carried out with DADA2 v. 1.14.1 (Callahan et al., 2016). Taxonomy assignment was made against the SILVA SSU database v. 138 (Quast et al., 2012) updated on august 15, 2020. Taxonomy and 
ASVs tables, as well as associated samples of metadata, were converted into a phyloseq object (McMurdie and Holmes, 2013) for further analysis. Bar plots, richness analyses as well richness plots for each sample were made with phyloseq and ggplot2 v.3.3.2 (Wickham, 2016).

\section{RESULTS}

\section{Mud mobility observed in RP}

Results derived from detailed structural mapping of the injected mud domes were combined with the analysis of the exposed stratigraphy variations and supported by the interpretation of GPR profiles. The map in Figure 3a shows 76 mud domes mapped on the surface in the western part of the crater, their spatial and size distribution, and the dome-size frequency (Figure 3b). The comparison of the stratigraphic sections with the GPR profiles show the relevant geological structures along the profiles (Figures $4 \mathrm{a}$ and $4 \mathrm{~b}$ ), including some of the faults at the main scarp bordering the sublittoral platform and the presence of a high conductivity zone associated with salt concentration in the central part of the lake floor (Figure 4c). A nearly horizontal reflector observed in both profiles is interpreted as the phreatic water level, marking the contact between relatively dry and brine-saturated mud. The depth of this reflector is about $2 \mathrm{~m}$ near the margins of the pelagic zone, and it decreases to $1.2 \mathrm{~m}$ near the residual brine pools
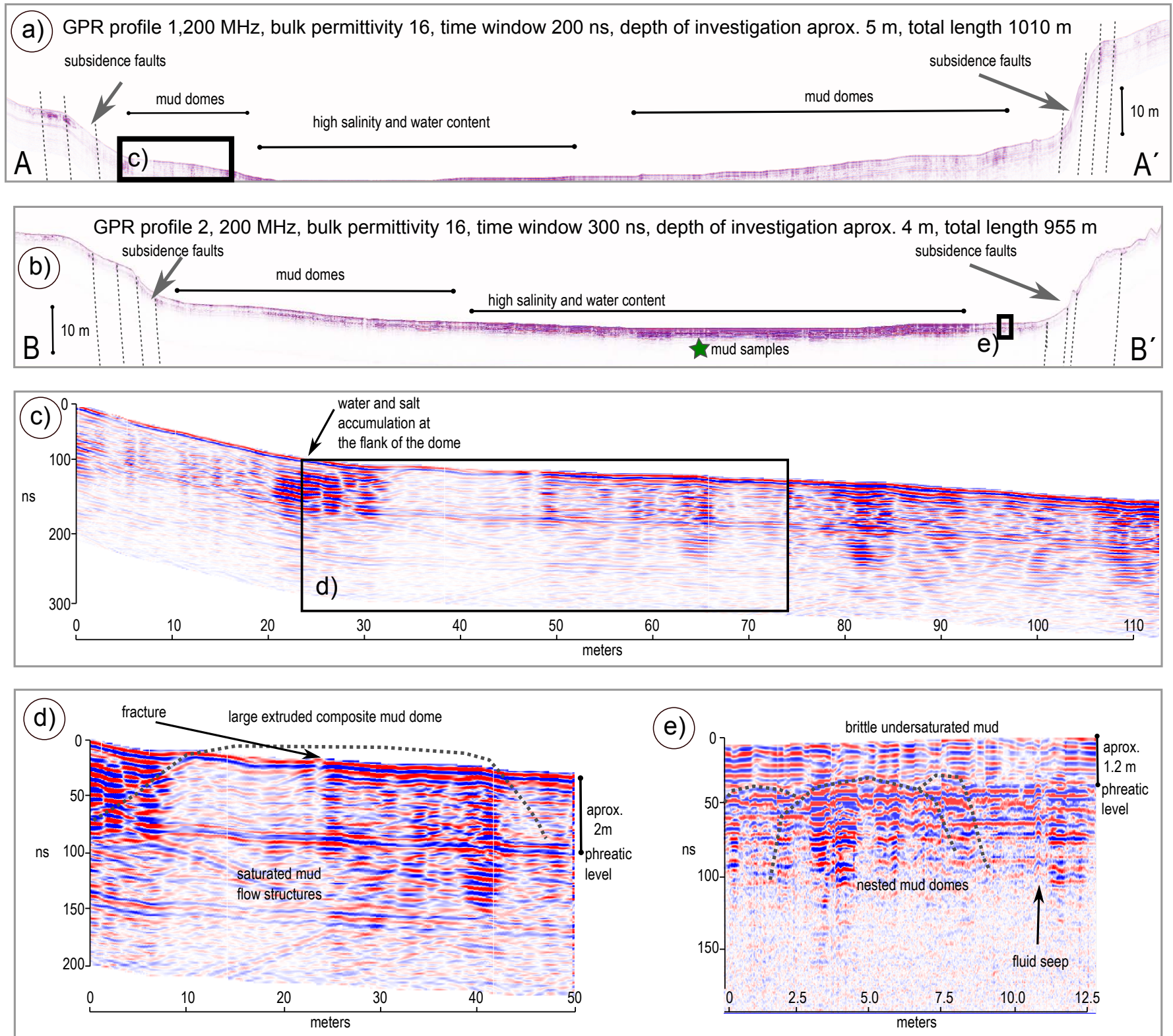

Figure. 4. Ground penetrating radar profiles of the dry lake bottom (see Figure 3 for location). a. Profile A-A' shows the location of the annular ring faults and the presence of underground mud domes exposed on the surface. b. Profile B-B'. The orthogonal projection of the location of the mud sampling sites used for DNA analysis is shown by a green star. c. Closer view of profile A-A' showing the geometry of the subsidence fault-scarp and the transitional changes toward the depocenter. d. Close up view of the domes. Discontinuous lines were added to enhance the interpreted structures. e. Small portion of the profile near the southern end of profile $\mathrm{B}-\mathrm{B}^{\prime}$. Above the water table reflector $(1.2 \mathrm{~m})$, mud is relatively dry with a volumetric water content increasing gradually from the surface from 30 to $150 \%$. Saturated mud forms domal structures that reach from below to the plastic-brittle transition. 
(Figures $4 \mathrm{~d}$ and $4 \mathrm{e}$ ). The change in the brine content of the mud also determines the mechanical behavior of the succession of sediments. Dry or unsaturated mud above the phreatic water level behaves as a brittle material and develops a network of dehydration fractures with a conspicuous polygonal array on the surface; whereas below the phreatic water level mud plasticity increases progressively until it displays a viscous fluid behavior (Aranda-Gómez et al., 2017). Extrusive mud seen in the core of the domes, such as the example presented in Figure 4d, dry and maintain their structure; whereas the mud below the phreatic level can be remobilized and form a new intrusion nearby. This is the case of the zones with a high density of domes such as the SW part of the maar. A contrasting case is shown in Figure 4e, where the saturated mud accumulates at the phreatic water level and starts to uplift forming a dome shape at the base of the brittle layer. We consider this situation as evidence for underground fluid input to the mud. Brine-saturated mud can maintain high mobility as long as it keeps a high fluid (groundwater and/or gas) content ( $\mathrm{W}_{\mathrm{V}}$ around $200 \%$ ) and it becomes immobile when pore pressure drops, and the mud dome becomes dry.

\section{Mud description}

The massive subsurface mobile mud of RP (Figure 2e) is characterized by silt and clay grain size, high alkalinity ( $\mathrm{pH} 10.38-10.65)$, high volumetric water content $\left(>200 \% \mathrm{~W}_{\mathrm{V}}\right)$, high conductivity (23.29$51.4 \mathrm{mS} / \mathrm{cm}$ ), organic-rich (>6\%), and strong $\mathrm{H}_{2} \mathrm{~S}$ smell. For the brine the dominant anion is $\mathrm{Cl}^{-}$and the dominant cation is $\mathrm{Na}^{+}$(Table 1). Low concentration of cations such as $\mathrm{Ca}^{+2}$ and $\mathrm{Mg}^{+2}$ identified in the samples is key to the chemical composition of the site because due to the shortage of these cations, anions such as $\mathrm{Cl}^{-}$and $\mathrm{CO}_{3}{ }^{2-}$ favor high alkalinity of the medium (e.g., Jones et al., 1998). Massive mud also has a high content of total organic matter of $6.77 \%$, which is evidenced by a characteristic black color, and might be related not only to the accumulation of plant- and animal-remains during a long depositional period but also to the biologic activity of the microbial community. SEM (Figures 5a and 5b) and DRX (Figures 5e and 5f) analyses of the mud show a highly porous structure with the presence of carbonates (aragonite: Ar; and hydromagnesite: Hy), salts (halite: $\mathrm{Ha}$ ), minor amounts of clay minerals (montmorillonite), and detrital quartz and feldspars. At higher magnification, the mud contains subhedral crystals of halite (Figure $5 \mathrm{c}$ and $5 \mathrm{~d}$ ). SEM images in cryo-fixed samples of the mud revealed evidence of microorganisms (Figure 6) embedded mostly in a porous, muddy network, which acts as a substrate for their growth.

\section{Microbial community composition observed in the mud brine}

Sedimentary environmental DNA (Ellegard et al., 2020) from three mud samples (Sed 1, Sed 2, and Sed 3) collected below the surface were analyzed for Bacteria and Archaea domains. The results include the

Table 1. Analysis of cations and anions in the brine (obtained by vacuum filtering) from two mud samples collected at 4 meters depth.

\begin{tabular}{lcc}
\hline & Sample 1 & Sample 2 \\
\hline $\mathrm{Na}(\mathrm{mg} / \mathrm{L})$ & 16263 & 6396 \\
$\mathrm{~K}(\mathrm{mg} / \mathrm{L})$ & 1733 & 766 \\
$\mathrm{P}(\mathrm{mg} / \mathrm{L})$ & 14.93 & 4.41 \\
$\mathrm{Ca}(\mathrm{mg} / \mathrm{L})$ & 3.42 & 2.91 \\
$\mathrm{Mg}(\mathrm{mg} / \mathrm{L})$ & 34 & 27 \\
$\mathrm{~S}(\mathrm{mg} / \mathrm{L})$ & 123 & 207 \\
$\mathrm{~K}(\mathrm{mg} / \mathrm{L})$ & 1733 & 766 \\
$\mathrm{~F}^{-}(\mathrm{mg} / \mathrm{L})$ & 39 & 12.50 \\
$\mathrm{Cl}^{-}(\mathrm{mg} / \mathrm{L})$ & 7564 & 2874 \\
$\mathrm{SO}_{4}^{2-}(\mathrm{mg} / \mathrm{L})$ & 771 & 114 \\
\hline
\end{tabular}

DNA from the actual living organisms and the preserved DNA from the past when the original mud layer was deposited at the surface. For the Bacteria domain the three samples could be characterized, but for the Archaea domain only the samples Sediment 2 and Sediment 3 had sequences that could be identified. Table 2 shows the concentrations obtained for each sample and their degree of purity (ratio 260/280). The highest yield was observed for Sediment 2 from which $32.41 \mathrm{ng}$ of DNA was obtained per $30 \mathrm{~g}$ of sample processed; the lowest yield was obtained for Sediment 3 with $16.67 \mathrm{ng}$ of DNA per $30 \mathrm{~g}$.

The number of filtered DNA sequences obtained for each of the samples is shown in Table 3. The minimum number of sequences obtained for a sample was about 5500, but most samples had at least 6000 sequences. The rarefaction curves were asymptotic, indicating that analyzing more sequences would yield only a limited number of more ASVs. The number of bacterial and archaeal ASVs ranged from 99 to 182. The $16 \mathrm{~S}$ rRNA phylogenetic analysis revealed a diverse microbial component. The bacterial assemblage was dominated by Cyanobacteria (20.2-69.1\%), Firmicutes (4.4-48.4 \%), Proteobacteria (15-30.6 \%), Bacteroidota (9.2-15.7\%) and, to a lesser extent, Actinobacteriota, Verrucomicrobiota, and Chloroflexi (Figure 7a). For samples Sediment 2 and Sediment 3, all the bacterial phyla were recognized but for sample Sediment 1, $0.54 \%$ of the sequences could not be classified. At order level, Synechococcales (11.1-48.5 \%), Cyanobacteriales (8.5-46.5\%), Lachnospirales (1.3-38.3\%), Bacteroidales (9.2-15.7\%), Rhodobacterales (9.1-13.4 \%), Phormidesmiales (1.9-11.4\%) were the better represented orders (Figure $7 \mathrm{~b}$ ). Alpha diversity metrics for the bacterial communities included observed richness (class level), Shannon-Weiner, and Simpson indices (Table 4 and Figure 8a).

For the Archaea domain, the most abundant microorganisms are related to Crenarchaeota (50-75.7\%), Halobacterota (13.6$27.2 \%)$, Hadarchaeota (8.5-8.6\%), Thermoplasmatota (1.1-7.2 \%), Euryarchaeota (0.5-1.3\%), and as minor components Nanoarchaeota and Asgardarchaeota. A small number of sequences were not classified (0.18-0.69 \%; Figure 7c). At order level (Figure 7d), Nitrososphaerales (38.6-45.8\%), Halobacterales (10.9-26.4 \%), and Hadarchaeia_or (8.5-8.6\%) sequences were obtained in high percentages. Additionally, Woesearchaeales, Thermoplasmatota_or, Methanomicrobiales, Methanomassiliicoccales, Methanobacteriales, and ANME-1b were identified in minor abundance. Observed richness, Shannon-Weiner, and Simpson indices values from archaeal communities recovered at subsurface in the RP lacustrine system are reported in Table 4 and Figure $8 \mathrm{~b}$.

\section{DISCUSSION}

\section{Fluid mobility}

Layers of lacustrine, organic rich, high porosity, massive clayey sediments in the crater of RP host mud mobilization and disrupt the original stratification of the ancient lake. This results in a highly dynamic geological environment. Disruption of the original stratification by the mud mobility has profound implications to the stability of the sedimentary record of RP that needs to be considered in other environmental studies that require a stable sedimentary layering. The high volumetric water content of these sediments $\left(>200 \% \mathrm{~W}_{\mathrm{V}}\right)$ and deformation of the lakebed causes slow pore fluid dissipation and mud overpressure (e.g., Revil, 2002). Eventually, mud ascends and is ejected locally in mud domes. More than 76 domes or small mud intrusions were found distributed mainly on the surface at the western portion of the subsiding bottom of the former lake at RP. Their size and ubiquitous presence indicates forced mud ascent to the surface from a shallow underground source. Differences observed in shapes of the 


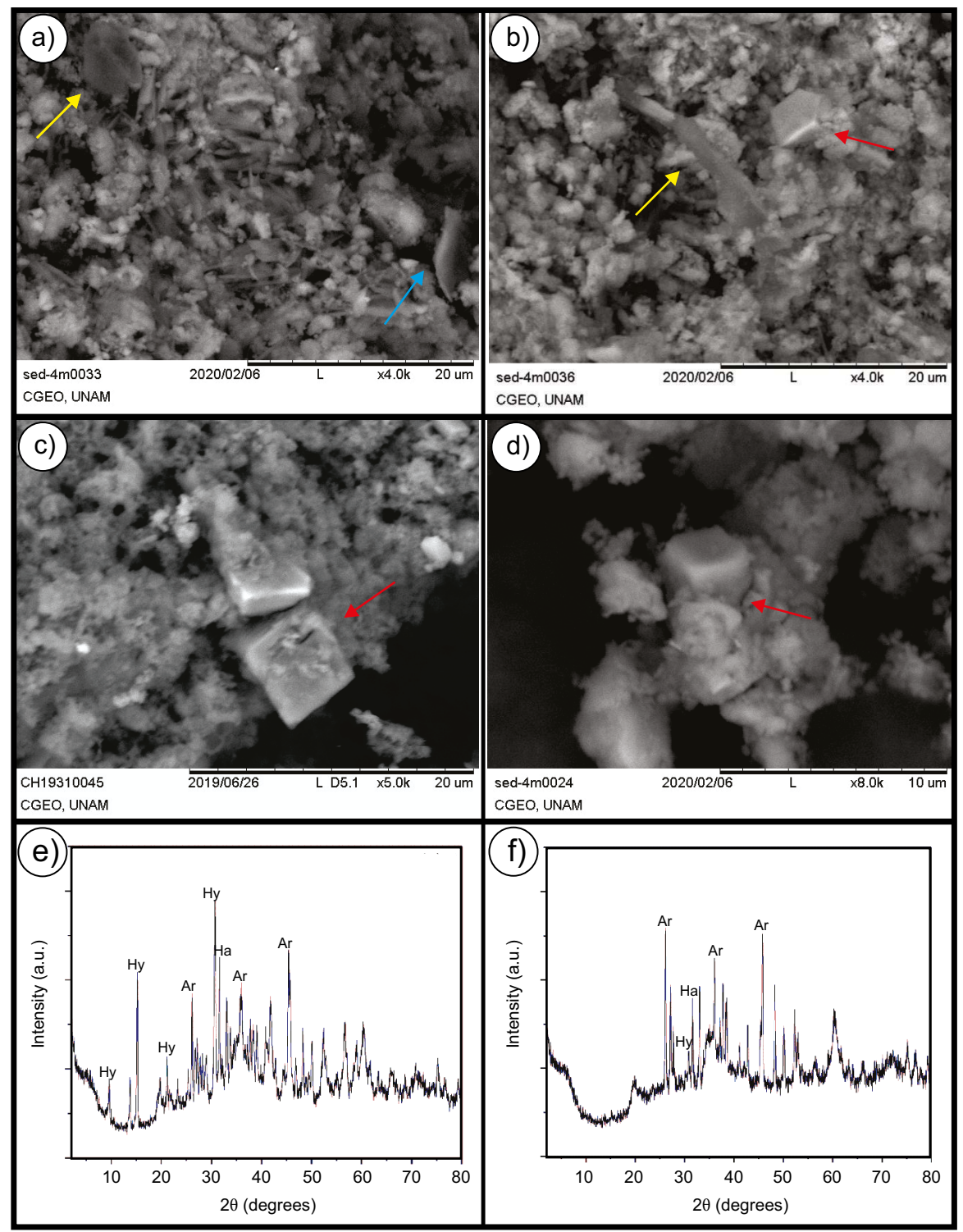

Figure. 5. SEM images and DRX analyses in selected mud samples collected at approx. $4 \mathrm{~m}$ below the surface. a. The image shows heterogeneous morphologies in the sediment and a highly porous structure. Clays are indicated with a blue arrow and a biological structure interpreted as a cell is also depicted (yellow arrow). b. Mineral and salt crystals (red arrow) occur near biological structures (yellow arrow). e, f. X-ray diffraction pattern of sediments showing peaks characteristic of aragonite (Ar), hydromagnesite (Hy) and Halite ( $\mathrm{Ha}$ ) which were observed in the sample, marked by red arrows in $\mathrm{c}$ and $\mathrm{d}$.

structures can be attributed to mud viscosity, differences in the brine and gas content and pore pressure of the mobile mud, and fracturing patterns in the unsaturated cap layer. When mud ascends to the surface it dries in a short period of time and the structures are preserved in the driest zone of the crater. Upward movement of mud is currently active as it has been observed the growth of larger domes and the emergence of new, smaller structures. Two main mechanisms responsible for the creation of fluid overpressure in RP mud are considered: a) disequilibrium compaction and b) gas input/generation (e.g., Wangen, 2001).

\section{Disequilibrium compaction}

Disequilibrium compaction results when mud is unable to drain fluids in response to loading or compressive stresses. Disequilibrium compaction forces mud to flow upwards. Structures that formed in close relation to mud displacement can be seen at the margins of the former lake including ductile deformation structures such as folds and the mud injections. The main geometrical and kinematic aspects of this deformation for the margin of the crater were explored and described in detail by Aranda-Gómez et al. (2017). In the case of RP, the injection domes formed by disequilibrium compaction show three different associations regarding their origin (Aranda-Gómez et al., 2017; Figure 3): a) Domes associated with compressive stresses generated by volume loss during fault displacement, these structures are generated by gravitational gliding/spreading and are between the largest domes in RP. The likely mechanism for the formation of these domes is overpressure formed at the diffuse detachment level that is associated with the gliding structures near the margin of the crater (Figure 4). b) Domes caused by local overpressure triggered by load associated with small landslides; these structures are formed in areas partially surrounded by megabreccias associated with landslides in areas where 


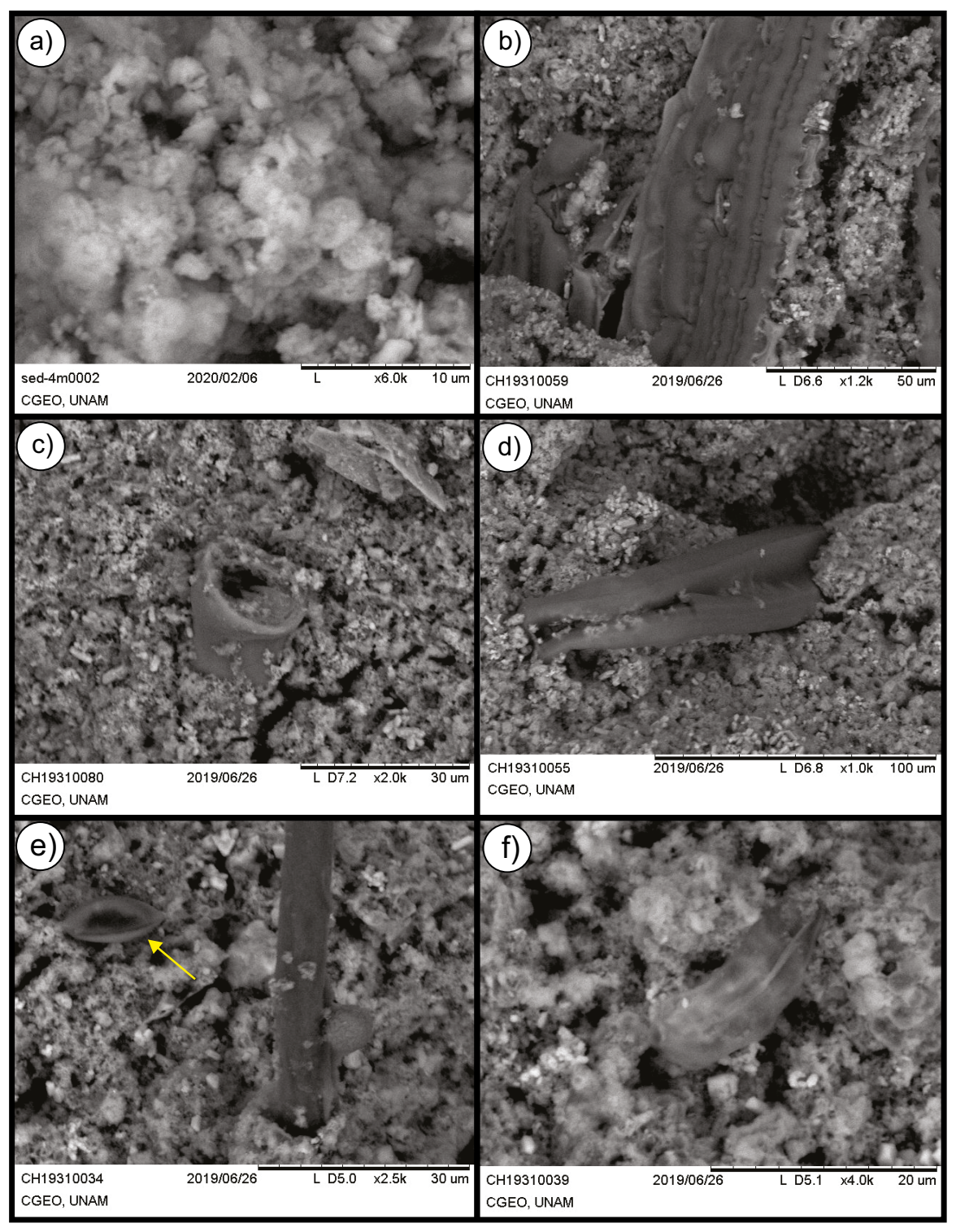

Figure. 6. SEM images of organic structures with different morphologies in the mud samples collected at $4 \mathrm{~m}$ depth. In all the photomicrographs sediment has a high porosity. a. Coccoid morphologies. b. A plant. c, d. Different biological morphologies embedded in the high porosity sediment. e. Two different biological morphologies, one of them similar to a diatom (Bacillariophyta: yellow arrow). f. A microorganism probably belonging to the Rotifera phylum.

the calcareous platform is nearly absent. The weight of the landslide deposit can produce overpressure in the underlying wet mud triggering mud injection (Figures 3 and 4); c) Domes and mud extrusion in portions of extensional faults/fractures. Massive mud concentrations with a characteristic "popcorn" weathering texture in relatively small, nearly circular areas suggest the presence of domes and/or "central vents" in areas at the carbonate platform scarp or in the pelagic zone. In cross-section wet mud appears to be injected in tensional fractures/ faults. These structures were interpreted in the GPR profiles as domes and mud uplifting associated with gas seeps (Figure 4e).

\section{Mud mobility possibly related to groundwater input and degassing in $R P$}

Fluid mobility and mud extrusion can also be associated with the volumetric expansion accompanying the phase change associated with gas generation in the pore system or from groundwater input (e.g.,
Revil, 2002). RP has previously been shown to emit fluids and gases. The present-day manifestations include soil degassing and pipe-like structures (Paz et al., 2020). Bubbling can be observed in remnant brine ponds. A recent study by Paz et al. (2020) has verified the emanation of gases such as $\mathrm{CO}_{2}$ with an estimated total flow of 10.6 ton $\cdot \mathrm{d}^{-1}$ and 6.3 ton $\mathrm{d}^{-1}$ of $\mathrm{CH}_{4}$ in RP. These authors suggest a strong biogenic contribution in the origin of methane, while $\mathrm{CO}_{2}$ is probably a mixing among volcanic and biologic sources mainly within sediments. Gas production may be a consequence of a prolonged phase of low volcanic activity (e.g., Loher et al., 2018) and/or result of underground biological activity. Small amounts of methane can produce expansion and drive extrusion (e.g., Brown, 1990).

A close spatial association of large domical biohermal thrombolites and the annular fault (i.e., the diatreme - country rock boundary; Lorenz, 1986) suggest that this structure might have controlled groundwater flow into the paleolake before desiccation (Aranda- 
Table 2. Total DNA obtained from $30 \mathrm{~g}$ of mud in the processed samples Sediment 1 , Sediment 2, and Sediment 3.

\begin{tabular}{lcccc}
\hline Sample & $\begin{array}{c}\text { Concentration } \\
(\mathrm{ng} / \mu \mathrm{l})\end{array}$ & $\begin{array}{c}\text { Total DNA } \\
(\mathrm{ng})\end{array}$ & $\begin{array}{c}\text { Volume } \\
(\mu \mathrm{l})\end{array}$ & $\begin{array}{c}\text { Relation } \\
\mathbf{2 6 0 / 2 8 0}\end{array}$ \\
\hline Sediment 1 & 0.80 & 22.33 & 27 & 1.67 \\
Sediment 2 & 1.16 & 32.41 & 27 & 1.75 \\
Sediment 3 & 0.60 & 16.67 & 27 & 1.65 \\
\hline
\end{tabular}

Gómez et al., 2017; Sánchez-Sánchez et al., 2019). Further evidence of this channelized, preferential groundwater flow includes the presence of chimney-like structures and the thrombolytic texture of most microbialites (Sánchez-Sánchez et al., 2019), which also suggests an upward groundwater flow during the lake period that might have helped to maintain a stable water level in the lake. The presence of springs associated with groundwater inflow was observed during the lake period in the past century (Escolero-Fuentes and Alcocer-Durán, 2004). We interpret this evidence as an indication of active input of fluids into the mud layer.

In the GPR profiles dome-shaped geometries were observed below the desiccated crust at the center of the crater, in areas not directly associated with the disequilibrium compaction in the margins. In this zone the surface dry mud crust forms a brittle cover atop the wet mud (Figure $4 \mathrm{~d}$ and $4 \mathrm{e}$ ). In the central part of the crater, we measured about $1.2 \mathrm{~m}$ of dry brittle mud three months after the end of the rainy season of 2018. The vertical transition between dry and wet mud in $\mathrm{RP}$ is diffuse because pore pressure increases with depth and almost certainly has a seasonal depth variation. In this setting, particularly at the western side of the lake bottom, wet mud has formed several diapirlike mud injections whose basal diameter varies from several tens of meters to less than one meter in diameter. These structures interpreted from the GPR profiles present surface evidence of fluid leakage as well as mud extrusion, indicated by the presence of a popcorn texture in the mud that reached the surface.

\section{Insights from the microbial communities DNA fingerprint documented in the mud}

This is the first study of sedimentary environmental DNA for identifying the bacterial and archaeal communities in the near-surface sediments of Rincón de Parangueo maar. Our results can provide an insight into the identities of members of the bacterial and archaeal communities in the three samples obtained in the crater discharging methane. As a prospective study, our results have limitations, one is the small number of samples collected (three) that prevent a complete statistical analysis among them. Despite this limitation, the high-quality data of the Bacteria and Archaea phylotypes allow us to calculate alpha diversity indices for each sample, making it possible to differentiate diversity values from previous studies in the area. Alpha diversity and observed ASVs of the bacterial and archaeal community measured in mud samples were lower than those reported by Ibarra-Sánchez et al. (2020) in superficial sediment samples. Despite physico-chemical parameters like grain size, alkalinity and conductivity were similar in both investigations, this downward trend in diversity values is consistent with the results, since it is known that the relative abundance of $16 \mathrm{~S}$ rRNA genes from Archaea and Bacteria generally decreases with depth of sediment (Hoshino and Inagaki, 2019). The results reveal a connection of the occurrence of specific microbes with the geological environment, can be particularly valuable for understanding community composition in future works, and give useful information on the relative importance of specific environmental drivers. Our interpretation is thus dependent not only on the DNA results but also
Table 3. Number of total sequences obtained from the sedimentary environmental DNA recovered of the highly mobile and saturated subsurface in the RP lacustrine system.

\begin{tabular}{lcc}
\hline Sample & Bacteria & Archaea \\
\hline Sediment 1 & 5408 & - \\
Sediment 2 & 12736 & 10089 \\
Sediment 3 & 7700 & 6335 \\
\hline
\end{tabular}

on understanding contemporary geological and ecological controls as well as the sedimentation environment and its context.

Additionally, sedimentary environmental DNA does not distinguish from living organisms or those derived from genetic archives of past environments preserved in dead cells, resting stages, or as an extracellular fraction in the mud (Torti et al., 2015; Vuillemin et al., 2017; Giguet-Covex et al., 2019). In RP, the persistence of extracellular DNA may be influenced by adsorbing to soil minerals. Silt and clay minerals could protect extracellular DNA from nuclease mediated enzymatic hydrolysation and by adsorbing DNases and nucleases, thereby reducing the potential for enzymatic DNA restriction (LevyBooth et al., 2007). Montmorillonite, a clay mineral identified in the mud samples (Armienta et al., 2008; Aranda-Gómez et al., 2013), has a higher DNA binding capacity than other minerals (e.g., kaolinite) (Pietramellara et al., 2001). The adsorption of DNA to clay minerals is enhanced by divalent cations like $\mathrm{Mg}^{2+}$ and $\mathrm{Ca}^{2+}$, also described for the samples, forming bridges between DNA and clay minerals above pH 5 (Levy-Booth et al., 2007). Mineral mud properties allow the conservation of extracellular DNA at high $\mathrm{pH}(>10)$ in RP. Thus, the sedimentary environmental DNA provides simultaneous information on multiple taxa potentially composed of phylotypes that live or lived in the sediments, probably within the last hundreds of years.

Our results suggest that the overall DNA fingerprint obtained shares similarities with the DNA of the microbial communities identified previously on the crater surface at the phylum level (SánchezSánchez et al., 2019; Ibarra-Sánchez et al., 2020). Bacteria phyla such as Cyanobacteria and Proteobacteria were abundant in two mud samples (this work, Sediment 1 and Sediment 3) as well as in the surface samples (Sánchez-Sánchez et al., 2019; Ibarra-Sánchez et al., 2020). Phyla identified in the mud such as Firmicutes, Actinobacteriota, Bacteroidota, Verrucomicrobiota, and Chloroflexi were also previously identified on the surface. These bacterial phyla dominate often in sediment samples of saline lakes (Vuillemin et al., 2018) and play an important role in biological cycles at these habitats. For instance, members of Proteobacteria, Firmicutes, Actinobacteriota, and Bacteroidota are heterotrophic organisms, so they are involved in processes of organic matter transformation (Sorokin et al., 2014; Ibarra-Sánchez et al., 2020). Phylotypes belonging to Firmicutes can fix nitrogen and members of Deltaproteobacteria and Firmicutes participate in the sulfur cycle (Sorokin et al., 2014).

The archaeal DNA obtained at depth in RP was classified into seven phyla: Crenarchaeota, Halobacterota, Hadarchaeota, Thermoplasmatota, Euryarchaeota, Nanoarchaeota, and Asgardarchaeota. Crenarchaeota was the most abundant phylum found in the mud at depth, in contrast to surface samples where the dominant phylum was Euryarchaeota (Sánchez-Sánchez et al., 2019; Ibarra-Sánchez et al., 2020). Crenarchaeota are globally ubiquitous, and members of this phylum are often the most abundant Archaea in various environments including marine sediments (Kubo et al., 2012) and salt marsh sediments (Seyler et al., 2014). Candidatus_Nitrososphaera, the dominant genus identified in mud samples for the Crenarchaeota phylum, is a moderately thermophilic microorganism $\left(46^{\circ} \mathrm{C}\right)$ with demonstrated 

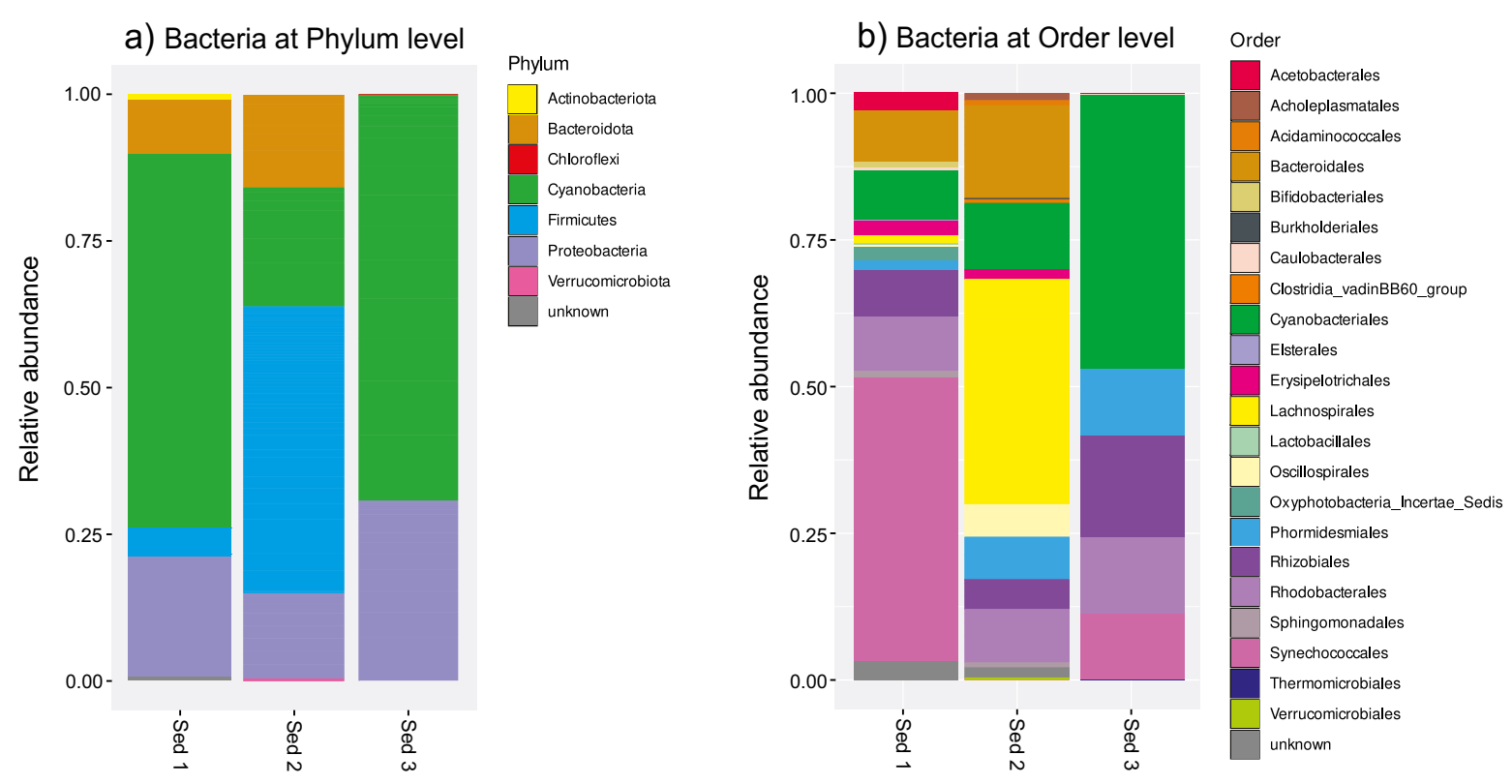

c) Archaea at Phylum level
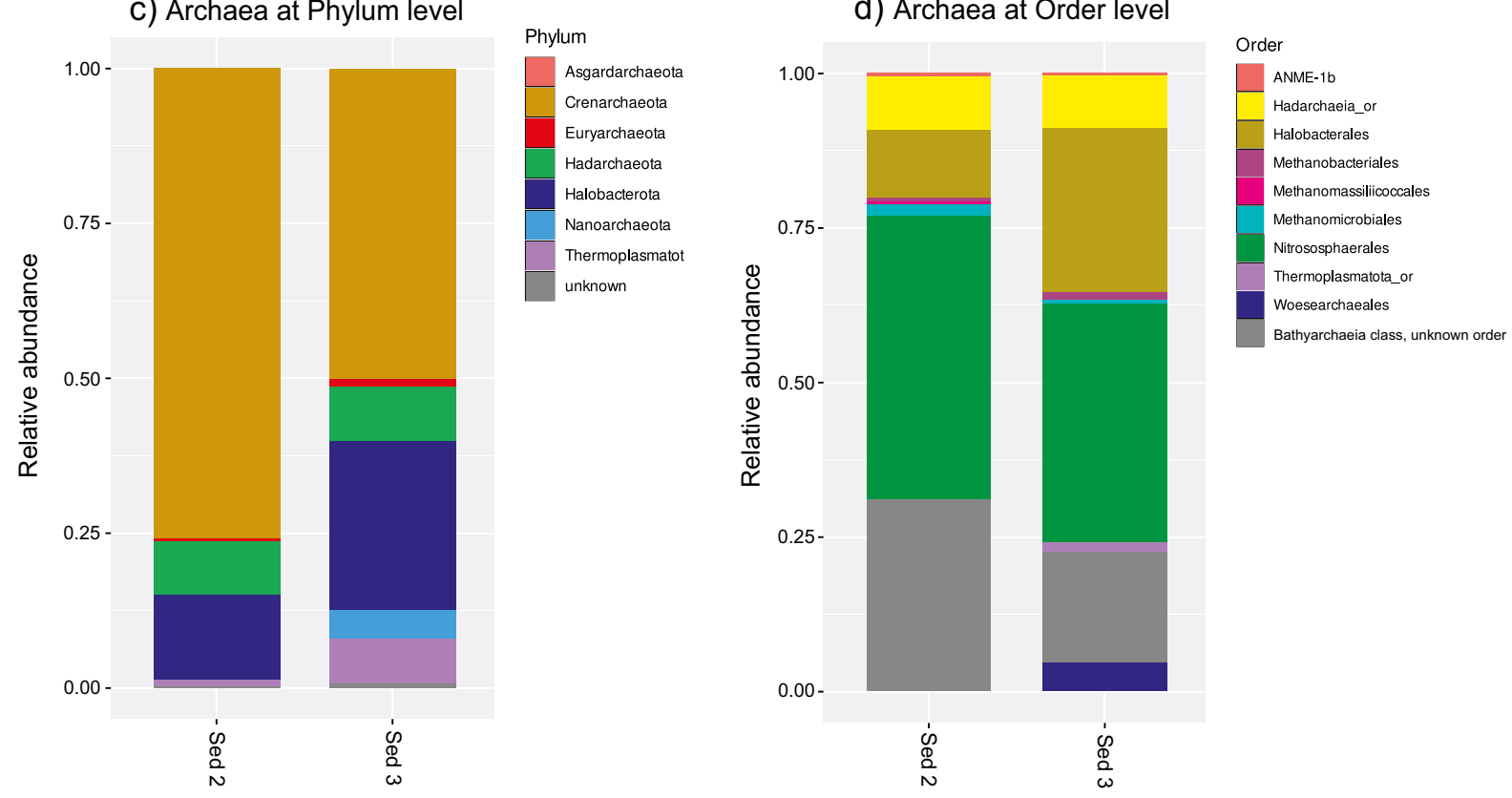

Figure. 7. Phylogenetic distribution of bacterial and archaeal 16S rRNA sequences in sediment samples from Rincón de Parangueo. a, b. Phylogenetic distribution of Bacteria at phylum and order level, showing the relative abundance for samples Sediment 1, Sediment 2 and Sediment 3. c, d. Phylogenetic distribution of Archaea at phylum and order level, for samples Sediment 2, and Sediment 3.

capacity for ammonia oxidation (Hatzenpichler et al., 2008). These archaeal genera have been found to be one of the dominant phylotype in hypersaline sediments from the saline-alkaline soils of the former lake Texcoco (Navarro-Noya et al., 2015) and, also was found by IbarraSánchez et al. (2020) as the dominant genera in superficial sediments samples $(0-20 \mathrm{~cm})$ in RP. Halobacterota, the second archaeal phylum most represented, are obligately halophilic (Papke et al., 2011), which explains their high relative abundance in the alkaline saline sediment of RP. Some habitats for these microorganisms are widespread around the world in salt lakes, hypersaline soils, underground salt deposits, and evaporation ponds (Oren et al., 1995; Arahal et al., 1996; Wainø et al., 2000; Mesbah et al., 2007; Papke et al., 2011; Kambura et al., 2016; Han et al., 2017).

\section{Methanogenic microorganisms and biogenic methane production in the sediments}

Phylotypes of methanogenic Archaea identified in RP comprise high percentages (13.2-32.1\%) of the total archaeal DNA, and include four phyla: Crenarchaeota, Halobacterota, Thermoplasmatota, and Euryarchaeota (Lyu et al., 2018). Archaea methanogenic microorganisms are strictly anaerobic and convert several substrates (i.e., $\mathrm{H}_{2}+\mathrm{CO}_{2}$, methyl compounds, and acetate) into methane gas in order to obtain energy. Methanogens groups occupy geothermal $\mathrm{CO}_{2}$ and $\mathrm{H}_{2}$ as the predominant substrates for methane production in places that emit gases, such as hot springs and volcanic fissures (Whitman et al., 2006), making them valuable for assessing volcanic degassing. Some of the organisms reported here have been found in deep sediments and 
Table 4. Observed richness, Shannon-Weiner and Simpson diversity index values from the sedimentary environmental DNA recovered at subsurface in the RP lacustrine system.

\begin{tabular}{lccc}
\hline Sample & \multicolumn{3}{c}{ Alpha diversity } \\
\cline { 2 - 4 } & $\begin{array}{c}\text { Observed } \\
\text { richness }\end{array}$ & $\begin{array}{c}\text { Shannon index } \\
\left(\mathrm{H}^{\prime}\right)\end{array}$ & $\begin{array}{c}\text { Simpson } \\
\text { index }\end{array}$ \\
\hline Sediment 1 Bacteria & 132 & 4.443 & 0.985 \\
Sediment 2 Bacteria & 84 & 4.066 & 0.976 \\
Sediment 3 Bacteria & 40 & 3.100 & 0.942 \\
Sediment 2 Archaea & 93 & 4.142 & 0.980 \\
Sediment 3 Archaea & 92 & 4.346 & 0.984 \\
\hline
\end{tabular}

soils elsewhere (Paul et al., 2012). The Bathyarchaeia class, member of Crenarchaeota, was previously reported in the deep sediment biosphere of lakes (Thomas et al., 2020) and subseafloor sediments (Kirkpatrick et al., 2019). Methane production by Bathyarchaeia was hypothesized by the metabolic reconstruction of its genome, the key genes associated with archaeal methane metabolism including methyl-coenzyme $M$ reductase complex suggests their potential for diverse methyl compound utilization for gas production (Evans et al., 2015). The order Methanomicrobiales of Halobacterota, is a hydrogenotrophic methanogen exclusively restricted to $\mathrm{CO}_{2}$ as a substrate for methanogenesis with the principal electron donor being $\mathrm{H}_{2}$ (Costa and Leigh, 2014). It has been previously reported in hot springs of the Central-Eastern Tibet (Huang et al., 2011), wetland soil (Tian et al., 2010), in two alkaline Indian hot springs (Panda et al., 2016), and soda lake sediments (Antony et al., 2012). The Methanomicrobiales and Methanomassiliicoccales orders of Thermoplasmatota use an external $\mathrm{H}_{2}$ source to reduce methyl-compounds into methane (Borrel et al., 2014). They were originally recognized in digestive tracts of animals (Poulsen et al., 2013) but also have been reported in natural wetlands, rice paddy fields, subseafloor and freshwater sediment (Borrel et al., 2013). Methanobacteriales is another hydrogenotrophic methanogen order found in this study belonging to the Euryarchaeota phylum (Buan, 2018). This order has been identified in sediments of fluvial (Chaudhary et al., 2017), lake (Yang et al., 2017), and mangrove environments (Li et al., 2016).

Based on the 16S rRNA results RP mud contains microorganisms with the potential to produce methane. Methylotrophic methanogens, the most represented methanogenic microorganisms in the sediment samples, are common in hypersaline and marine sediments (Lyu et al., 2018). Obligately methylotrophic methanogens have an ecological advantage over other groups of methanogens since they utilize compounds such as methanol and methylated amines, avoid competition with sulfate-reducing Bacteria also present in this type of environments (Antony et al., 2012). Methanogenic Archaea use organic solutes for osmotic stabilization in hypersaline environments at a high energetic cost, methylotrophic methanogenesis produces more energy than methanogenesis from acetate and $\mathrm{CO}_{2}$ reduction (Oren, 2001). The greatest amount of energy generated by this type of methanogenesis may provide a possible explanation for why methanogenesis on methylated compounds is more feasible at the high salt concentrations in the RP sediments. On the other hand, hydrogenotrophic methanogenesis suggested by the identification of Methanomicrobiales and Methanobacteriales phylotypes could be explained by the presence of post eruptive gases still released in the RP crater. The huge amounts of $\mathrm{CO}_{2}$ gas verified by Paz et al. (2020) could be being reduced by methanogenic Archaea for methane formation.

Mud in RP could be considered as analogue habitats of fluidized mobile muds in submarine mud volcanoes, since they consist of a mixture of fine-grained, fluid-rich mobile sediment (i.e., Pachiadaki et al., 2011). Active fluid seepage and gas bubble release are common in other similar environments such as submarine mud volcanoes driven by overpressured subsurface sediment found at tectonically active and passive continental margins (Lazar et al., 2011). Mud volcanoes emitting biogenic methane have been characterized by previous molecular genetic analyses, detecting the three methanogenic pathways (methylotrophic, hydrogenotrophic and acetoclastic) (e.g., Lazar et al., 2011; Lazar et al., 2012). These former authors report that methylotrophic methanogenesis was the most active process in a mud volcano where hypersaline conditions persist.

\section{CONCLUSION}

We report the presence of a layer of mobile mud below the surface of the crater RP. Mud is organic rich, high porosity, with high volumetric water ( $>200 \% \mathrm{~W}_{\mathrm{V}}$ ), massive, clayey, and has a sedimentary origin. This mud layer hosts present-day mobilization triggered by two combined processes, disequilibrium compaction and pore over- a) Bacteria

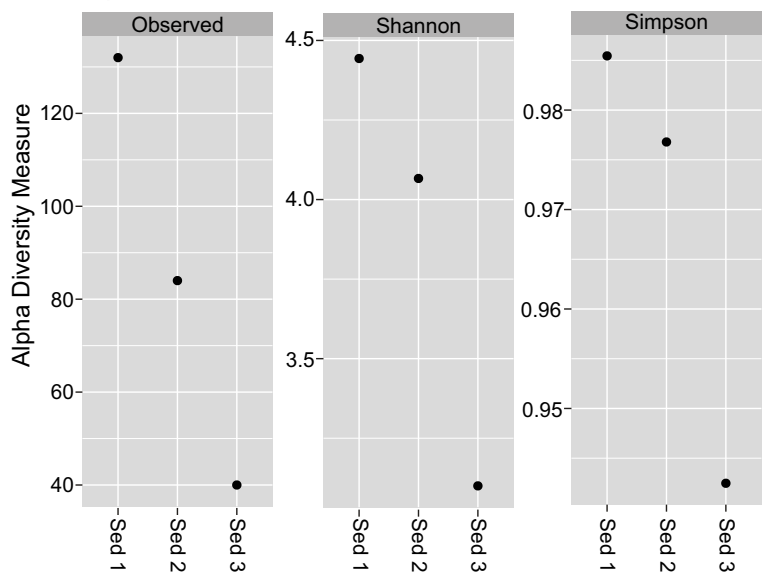

b) Archaea

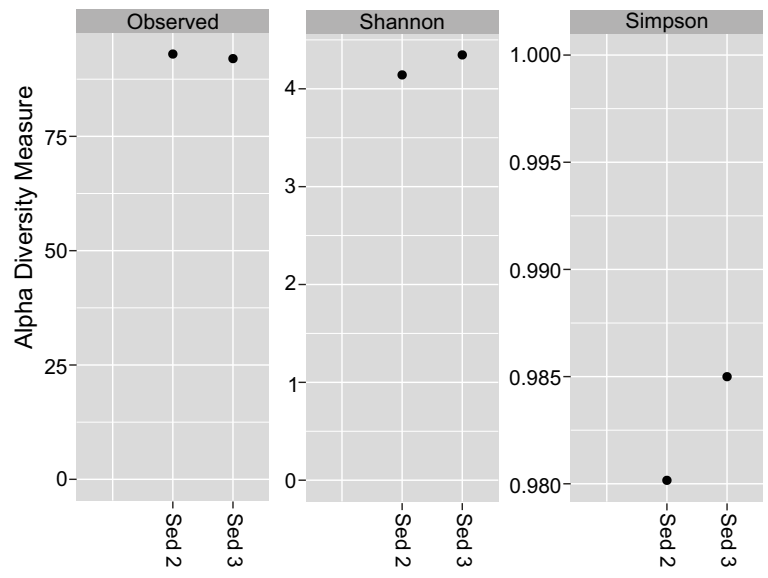

Figure. 8. Observed counts and alpha diversity measured by the Shannon and Simpson indices. a. Observed counts and alpha diversity for Bacteria in samples Sediment 1, Sediment 2, and Sediment 3. b. Observed counts and alpha diversity for Archaea in samples Sediment 2 and Sediment 3. 
pressure enhanced by an input of groundwater and gas content in the sediments. Mud mobilization disrupted the stratification of the ancient lake and produced mud tectonic structures such as injection mud domes, recorded in field and in GPR profiles. Mud ascends from a shallow underground source to the surface and results in more than 76 domes or small mud intrusions distributed mainly at the western portion of the former lake at RP.

The microbial communities' fingerprint, or sedimentary environmental DNA, documented in the mud provide an insight into the identities of members of the bacterial and archaeal communities in three mud samples, and allow to discuss the probable role played by biogenic methane in mud mobilization observed on the surface. We emphasize that given the small number of samples available for this work, the details of the methanogenic activity in the RP sediments needs to be corroborated with further and more detailed studies. We hypothesize that pore pressure in the mud may periodically be increased as a consequence of microbe's activity; for instance, the biogenic degradation of organic matter (i.e., methanogenesis). We identified methanogenic microorganisms in the DNA fingerprint. The phylotypes Bathyarchaeia, Methanomicrobiales, Methanomassiliicoccales, and Methanobacteriales were recognized in the mud samples, giving way to the possibility of biogenic gas production by them. Analogue habitats of fluidized or mobile muds are those observed in brine-sediments (mud volcanoes) driven by overpressured subsurface sediment where methanogenic microorganisms have an active influence in the methane fluxes. Coupling the geological and microbiotic factors can provide a holistic view of this dynamic extreme environment.

\section{ACKNOWLEDGMENTS}

We thank Sara Solís Valdez, Marina Vega, Ricardo Carrizosa and María Carolina Muñoz Torres for help on the soil and water analysis, and Luis Aguilar, Alejandro de León, Carlos S. Flores and Jair García of the Laboratorio Nacional de Visualización Científica Avanzada (UNAM) for assistance in the bioinformatic analysis. Barbara Moguel is thanked for help on the DNA analysis. We thank Dante Morán-Zenteno and two anonymous reviewers for their revision that helped to improve this work. This work was supported by projects of the Laboratorio de Mecánica de Geosistemas (LAMG, UNAM). Sánchez-Sánchez received a PhD scholarship from Consejo Nacional de Ciencia y Tecnología (CONACyT).

\section{REFERENCES}

Antony, C.P., Murrell, J.C., Shouche, Y.S., 2012, Molecular diversity of methanogens and identification of Methanolobus sp. as active methylotrophic Archaea in Lonar crater lake sediments: FEMS Microbiology Ecology, 81, 43-51, https://doi.org/10.1111/j.1574-6941.2011.01274.x

Arahal, D.R., Dewhirst, F.E., Paster, B.J., Volcani, B.E., Ventosa, A., 1996, Phylogenetic analyses of some extremely halophilic archaea isolated from Dead Sea water, determined on the basis of their $16 \mathrm{~S}$ rRNA sequences: Applied and Environmental Microbiology, 62(10), 3779-3786.

Aranda-Gómez, J.J., Cerca, M., Rocha-Treviño, L., Pacheco, J., Levresse, G., Ramos-Leal, J.A., Yutsis, V., Arzate-Flores, J.A., 2014, Structural analysis of subsidence-related deformation at the bottom of Rincón de Parangueo maar, México, in Proceedings IAVCEI-5th International Maar Conference: Querétaro, Mexico, Centro de Geociencias, Universidad Nacional Autónoma de México, 174-175.

Aranda-Gómez, J.J., Cerca, M., Rocha-Treviño, L., Carrera-Hernández, J.J., Levresse, G., Pacheco, J., Yutsis, V., Arzate-Flores, J.A., Chacón, E., BeraldiCampesi, H., 2017, Structural evidence of enhanced active subsidence at the bottom of a maar: Rincón de Parangueo, México: Geological Society, London, Special Publications, 446(1), 225-254.
Aranda-Gómez, J.J., Levresse, G., Martínez, J.P., Ramos-Leal, J.A., CarrascoNúñez, G., Chacón-Baca, E., González-Naranjo, G., Chávez-Cabello, G., Vega-González, M., Origel, G., 2013, Active sinking at the bottom of the Rincón de Parangueo maar (Guanajuato, México) and its probable relation with subsidence faults at Salamanca and Celaya: Boletín de la Sociedad Geológica Mexicana, 65(1), 169-188.

Armienta, M. A., Vilaclara, G., De la Cruz-Reyna, S., Ramos, S., Ceniceros, N., Cruz, O., Aguayo, A., Arcega-Cabrera, F., 2008, Water chemistry of lakes related to active and inactive Mexican volcanoes: Journal of Volcanology and Geothermal Research, 178(2), 249-258.

Bey, B.S., Fichot, E.B., Dayama, G., Decho, A.W., Norman, R.S., 2010, Extraction of high molecular weight DNA from microbial mats: Biotechniques, 49(3), 631-640.

Bolger, A.M., Lohse, M., Usadel, B., 2014, Trimmomatic: a flexible trimmer for Illumina sequence data: Bioinformatics, 30, 2114-2120, https://doi. org/10.1093/bioinformatics/btu170

Borrel, G., O’Toole, P.W., Harris, H.M., Peyret, P., Brugere, J.-F., Gribaldo, S., 2013, Phylogenomic data support a seventh order of methylotrophic methanogens and provide insights into the evolution of methanogenesis: Genome Biology and Evolution, 5(10), 1769-1780.

Borrel, G., Parisot, N., Harris, H.M., Peyretaillade, E., Gaci, N., Tottey, W., Bardot, O., Raymann, K., Gribaldo, S., Peyret, P., 2014, Comparative genomics highlights the unique biology of Methanomassiliicoccales, a Thermoplasmatales-related seventh order of methanogenic archaea that encodes pyrrolysine: BMC Genomics, 15(1), 1-24, https://doi. org/10.1186/1471-2164-15-679

Brown, K.M., 1990, The nature and hydrogeologic significance of mud diapirs and diatremes for accretionary systems: Journal of Geophysical Research: Solid Earth, 95(B6), 8969-8982.

Buan, N.R., 2018, Methanogens: Pushing the boundaries of biology: Emerging Topics in Life Sciences, 2(4), 629-646, https://doi.org/10.1042/ ETLS20180031

Callahan, B.J., McMurdie, P.J., Rosen, M.J., Han, A.W., Johnson, A.J.A., Holmes, S.P., 2016, Dada2: High-resolution sample inference from illumina amplicon data: Nature Methods, 13(7), 581-583, https://doi.org/10.1038/ nmeth.3869

Carreón-Freyre, D., Cerca, M., Hernández-Marín, M., 2003, Correlation of near-surface stratigraphy and physical properties of clayey sediments from Chalco basin, México, using ground penetrating radar: Journal of Applied Geophysics, 53(2-3), 121-136, https://doi.org/10.1016/ S0926-9851(03)00042-9

Cerca, M., Carreón-Freyre, D., Aranda-Gómez, J.J., Rocha-Treviño, L., 2014, GPR profiles for characterizing subsidence deformation in lake sediments within a maar cráter, in Proceedings of the $15^{\text {th }}$ International Conference on Ground Penetrating Radar: Brussels, Belgium, IEEE Xplore, 274-278, doi: 10.1109/ICGPR.2014.6970428

Cerca, M., Rocha, L., Carreón-Freyre, D., Aranda, J., 2015, Physical experiments of land subsidence within a maar crater: Insights for porosity variations and fracture localization: Proceedings of the International Association of Hydrological Sciences, 372, 285-290, https://doi.org/10.5194/ piahs-372-285-2015

Chacón, E., Aranda-Gómez, J.J., Charles-Polo, M., Sánchez-Ramos, M.A., Rivera-Muñoz, E.M., Levresse, G., Millán-Malo, B., 2018, Biohermal thrombolites of the crater lake Rincón de Parangueo in central México: Journal of South American Earth Sciences, 85, 236-49, https://doi. org/10.1016/j.jsames.2018.04.013

Chaudhary, P.P., Rulík, M., Blaser, M., 2017, Is the methanogenic community reflecting the methane emissions of river sediments? comparison of two study sites: Microbiology Open, 6(4), e00454, https://doi.org/10.1002/ mbo3.454

Core, Team., 2020, R: A language and environment for statistical computing. $\mathrm{R}$ Foundation for Statistical Computing: Vienna, Austria, computer software availale at https://www.R-project.org/

Costa, K.C., Leigh, J.A., 2014, Metabolic versatility in methanogens: Current Opinion in Biotechnology, 29, 70-75, https://doi.org/10.1016/j. copbio.2014.02.012

Domínguez-Vázquez, G., Osuna-Vallejo, V., Castro-López, V., IsradeAlcántara, I., Bischoff, J.A., 2019, Changes in vegetation structure during the Pleistocene-Holocene transition in Guanajuato, central México: Vegetation History and Archaeobotany, 28(1), 81-91, https://doi. org/10.1007/s00334-018-0685-8 
Ellegaard, M., Clokie, M.R.J., Czypionka, T., 2020, Dead or alive: sediment DNA archives as tools for tracking aquatic evolution and adaptation: Commun Biol, 3 (1), 1-11, https://doi.org/10.1038/s42003-020-0899-z

Escolero-Fuentes, Ó, A., Alcocer-Durán, J., 2004, Desecación de los lagos cráter del Valle de Santiago, Guanajuato, in Jiménez, B., Marín, L., (eds.), El Agua en México vista desde la Academia: México City, Academia Mexicana de Ciencias, 99-115.

Evans, P.N., Parks, D.H., Chadwick, G.L., Robbins, S.J., Orphan, V.J., Golding, S.D., Tyson, G.W., 2015, Methane metabolism in the archaeal phylum bathyarchaeota revealed by genome-centric metagenomics: Science, 350(6259), 434-438, https://doi.org/10.1126/science.aac7745

Gates-Rector, S., Blanton, T., 2019, The powder diffraction file: a quality materials characterization database: Powder Diffraction, 34(4), 352-360.

Giguet-Covex, C., Ficetola, G.F., Walsh, K., Poulenard, J., Bajard, M., Fouinat, L., Sabatier, P., Gielly, L., Messager, E., Develle, A.L., 2019, New insights on lake sediment DNA from the catchment: Importance of taphonomic and analytical issues on the record quality: Scientific Reports, 9(1), 1-21, https://doi.org/10.1038/s41598-019-50339-1

Han, R., Zhang, X., Liu, J., Long, Q., Chen, L., Liu, D., Zhu, D., 2017, Microbial community structure and diversity within hypersaline Keke salt lake environments: Canadian Journal of Microbiology, 63(11), 895-908, https:// doi.org/10.1139/cjm-2016-0773

Hatzenpichler, R., Lebedeva, E.V., Spieck, E., Stoecker, K., Richter, A., Daims, H., Wagner, M., 2008, A moderately thermophilic ammonia-oxidizing Crenarchaeote from a hot spring: Proceedings of the National Academy of Sciences, 105(6), 2134-2139, https://doi.org/10.1073/pnas.0708857105

Hautman, D.P., Munch, D.J., 1997, Method 300.1 determination of inorganic anions in drinking water by ion chromatography: Cincinnati, OH, US Environmental Protection Agency, 1-36.

Hoshino, T., Inagaki, F., 2019, Abundance and distribution of Archaea in the subseafloor sedimentary biosphere: The ISME Journal, 13(1), 227-231.

Huang, Q., Dong, C.Z., Dong, R.M., Jiang, H., Wang, S., Wang, G., Fang, B., Ding, X., Niu, L., Li, X., 2011, Archaeal and bacterial diversity in hot springs on the Tibetan Plateau, China: Extremophiles, 15(5), 549, DOI: 10.1007/s00792-011-0386-Z

Ibarra-Sánchez, C.L., Prince, L., Aguirre-Noyola, J.L., Sánchez-Cerda, K.E., Navaro-Noya, Y.E., Luna-Guido, M., Conde-Barajas, E., Dendooven, L., Gomez-Acata, E.S., 2020, The microbial community in an alkaline saline sediment of a former maar lake bed: Journal of Soils and Sediments, 20(1), 542-555, https://doi.org/10.1007/s11368-019-02371-x

Jones, B.E., Grant, W.D., Duckworth, A.W., Owenson, G.G., 1998, Microbial diversity of soda lakes: Extremophiles, 2(3), 191-200.

Kambura, A.K., Mwirichia, R.K., Kasili, R.W., Karanja, E.N., Makonde, H.M., Boga, H.I., 2016, Bacteria and Archaea diversity within the hot springs of Lake Magadi and Little Magadi in Kenya: BMC Microbiology, 16(1), 136, https://doi.org/10.1186/s12866-016-0748-x

Kienel, U., Bowen, S.W., Byrne, R., Park, J., Böhnel, H., Dulski, P., Luhr, J.F., Siebert, L., Haug, G.H., Negendank, J.F., 2009, First lacustrine varve chronologies from México: Impact of droughts, ENSO and human activity since AD 1840 as recorded in maar sediments from Valle de Santiago: Journal of Paleolimnology, 42(4), 587-609.

Kirkpatrick, J.B., Walsh, E.A., D’Hondt, S., 2019, Microbial selection and survival in subseafloor sediment: Frontiers in Microbiology, 10, 956, https://doi. org/10.3389/fmicb.2019.00956

Kubo, K., Lloyd, K.G., Biddle, J.F., Amann, R., Teske, A., Knittel, K., 2012, Archaea of the Miscellaneous Crenarchaeotal Group are abundant, diverse and widespread in marine sediments: The ISME Journal, 6(10), 1949-1965, https://doi.org/10.1038/ismej.2012.37

Lay, C. Y., Mykytczuk, N. C., Yergeau, É., Lamarche-Gagnon, G., Greer, C. W., Whyte, L, G., 2013, Defining the functional potential and active community members of a sediment microbial community in a high-arctic hypersaline subzero spring: Applied and Environmental Microbiology, 79(12), 3637-3648

Lazar, C. S., John Parkes, R., Cragg, B. A., l'Haridon, S., Toffin, L., 2012, Methanogenic activity and diversity in the centre of the Amsterdam Mud Volcano, Eastern Mediterranean Sea: FEMS Microbiology Ecology, 81(1), 243-254.

Lazar, C. S., Parkes, R. J., Cragg, B. A., l'Haridon, S., Toffin, L., 2011, Methanogenic diversity and activity in hypersaline sediments of the centre of the Napoli mud volcano, Eastern Mediterranean Sea: Environmental Microbiology,
13(8), 2078-2091.

Levy-Booth, D.J., Campbell, R.G., Gulden, R.H., Hart, M.M., Powell, J.R., Klironomos, J.N., Dunfield, K.E., 2007, Cycling of extracellular DNA in the soil environment: Soil Biology and Biochemistry, 39(12), 2977-2991.

Levresse, G., Aranda-Gómez, J.J., Bard R.C., Cerca, M., Rocha-Treviño, L., Pacheco-Martínez, J., Ramos-Leal, J.A., Yutsis, V., Arzate-Flores, J. 2014, COB isotopic evolution of lacustrine microbialites of Rincón de Parangueo maar, México, in Proceedings IAVCEI-5th International Maar Conference: Querétaro, Mexico, Centro de Geociencias, Universidad Nacional Autónoma de México, 132-133.

Li, W., Guan, W., Chen, H., Liao, B., Hu, J., Peng, C., Rui, J., Tian, J., Zhu, D., He, Y., 2016, Archaeal communities in the sediments of different mangrove stands at Dongzhaigang, China: Journal of Soils and Sediments, 16(7), 1995-2004, https://doi.org/10.1007/s11368-016-1427-0

Loher, M., Pape, T., Marcon, Y., Römer, M., Wintersteller, P., Praeg, D., Torres, M., Sahling, H., Bohrmann, G., 2018, Mud extrusion and ring-fault gas seepage-upward branching fluid discharge at a deep-sea mud volcano: Scientific Reports, 8(1), 1-11, https://doi.org/10.1038/s41598-018-24689-1

Lorenz, V., 1986, On the growth of maars and diatremes and its relevance to the formation of tuff rings: Bulletin of Volcanology, 48(5), 265-274, https:// doi.org/10.1007/BF01081755

Lyu, Z., Shao, N., Akinyemi, T., Whitman, W.B., 2018, Methanogenesis: Current Biology, 28(13), R727-R732, DOI: 10.1016/j.cub.2018.05.021

McMurdie, P.J., Holmes, S., 2013, phyloseq: an R package for reproducible interactive analysis and graphics of microbiome census data: PloS One, 8, e61217, https://doi.org/10.1371/journal.pone.0061217

Mesbah, N.M., Abou-El-Ela, S.H., Wiegel, J., 2007, Novel and unexpected prokaryotic diversity in water and sediments of the alkaline, hypersaline lakes of the Wadi and Natrun, Egypt: Microbial Ecology, 54(4), 598-617, https://doi.org/10.1007/s00248-006-9193-y

Navarro-Noya, Y.E., Valenzuela-Encinas, C., Sandoval-Yuriar, A., JiménezBueno, N.G., Marsch, R., Dendooven, L., 2015, Archaeal communities in a heterogeneous hypersaline-alkaline soil: Archaea, 2015, 646820.

NOM-021-RECNAT-2000, Norma Oficial Mexicana que establece las especificaciones de fertilidad, salinidad y clasificación de suelos. Estudio, muestreo y análisis: México, D.F., Mexico, Diario Oficial de la Federación, 2002, 1-22.

Oren, A., 2001, The bioenergetic basis for the decrease in metabolic diversity at increasing salt concentrations: implications for the functioning of salt lake ecosystems, in Melack, M., Jellison, R., Herbst, D.B., (eds.), Saline Lakes: Springer, 61-72, https://doi.org/10.1007/978-94-017-2934-5_6

Oren, A., Gurevich, P., Gemmell, R.T., Teske, A., 1995, Halobaculum gomorrense gen. Nov., sp. Nov., a novel extremely halophilic archaeon from the Dead Sea: International Journal of Systematic and Evolutionary Microbiology, 45(4), 747-754, https://doi.org/10.1099/00207713-45-4-747

Pachiadaki, M. G., Kallionaki, A., Dählmann, A., De Lange, G. J., Kormas, K. A., 2011, Diversity and spatial distribution of prokaryotic communities along a sediment vertical profile of a deep-sea mud volcano: Microbial Ecology, 62(3), 655-668.

Panda, A.K., Bisht, S.S., De Mandal, S., Kumar, N.S., 2016, Bacterial and archeal community composition in hot springs from Indo-Burma region, North-east India: AMB Express, 6(1), 111, https://doi.org/10.1186/ s13568-016-0284-y

Papke, R.T., White, E., Reddy, P., Weigel, G., Kamekura, M., Minegishi, H., Usami, R., Ventosa, A., 2011, A multilocus sequence analysis approach to the phylogeny and taxonomy of the Halobacteriales: International Journal of Systematic and Evolutionary Microbiology, 61(12), 2984-2995, https:// doi.org/10.1099/ijs.0.029298-0

Paul, K., Nonoh, J.O., Mikulski, L., Brune, A., 2012, "Methanoplasmatales", Thermoplasmatales-related archaea in termite guts and other environments, are the seventh order of methanogens: Applied and Environmental Microbiology, 78(23), 8245-8253.

Paz, M.P.J., Inguaggiato, C., Levresse, G., Robidoux, P., Granados, H.D., Tassi, F., 2020, Total $\mathrm{CO}_{2}$ output and carbon origin discharged from Rincón de Parangueo maar (México): Journal of Geochemical Exploration, 106558, https://doi.org/10.1016/j.gexplo.2020.106558

Pietramellara, G., Franchi, M., Gallori, E., Nannipieri, P., 2001, Effect of molecular characteristics of DNA on its adsorption and binding on homoionic montmorillonite and kaolinite: Biology and Fertility of Soils, $33,402-409$. 
Poulsen, M., Schwab, C., Jensen, B.B., Engberg, R.M., Spang, A., Canibe, N. Højberg, O., Milinovich, G., Fragner, L., Schleper, C., 2013, Erratum: Methylotrophic methanogenic Thermoplasmata implicated in reduced methane emissions from bovine rumen: Nature Communications, 4(1), 1-2, https://doi.org/10.1038/ncomms2432

Quast, C., Pruesse, E., Yilmaz, P., Gerken, J., Schweer, T., Yarza, P., Peplies, J., Glöckner, F.O., 2012, The SILVA ribosomal RNA gene database project: improved data processing and web-based tools: Nucleic Acids Research, 4, D590-D596, https://doi.org/10.1093/nar/gks1219

Revil, A., 2002, Genesis of mud volcanoes in sedimentary basins: A solitary wave-based mechanism: Geophysical Research Letters, 29(12), 15-1-15-4, https://doi.org/10.1029/2001GL014465

Rocha-Treviño, L., 2015, Análisis de la deformación y hundimiento activo causado por la desecación del lago del maar Rincón de Parangueo (Guanajuato, México) mediante modelos análogos y perfiles de Radar de Penetración Terrestre (RPT): Querétaro, Qro. Mexico, Universidad Nacional Autónoma de México, Master's thesis, 87 pp, https://repositorio. unam.mx/contenidos/65241

Sánchez-Sánchez, J., Cerca, M., Alcántara-Hernández, R.J., Lozano-Flores, C., Carreón-Freyre, D., Levresse, G., Vega, M., Varela-Echavarría, A., ArandaGómez, J.J., 2019, Extant microbial communities in the partially desiccated Rincon de Parangueo maar crater lake in Mexico: FEMS Microbiology Ecology, 95(5), fiz051, https://doi.org/10.1093/femsec/fiz051

Seyler, L.M., McGuinness, L.M., Kerkhof, L.J., 2014, Crenarchaeal heterotrophy in salt marsh sediments: The ISME Journal, 8(7), 1534-1543, https://doi. org/10.1038/ismej.2014.15

Sorokin, D. Y., Berben, T., Melton, E. D., Overmars, L., Vavourakis, C. D., Muyzer, G., 2014, Microbial diversity and biogeochemical cycling in soda lakes: Extremophiles, 18(5), 791-809, https://doi.org/10.1007/ s00792-014-0670-9

Thomas, C., Francke, A., Vogel, H., Wagner, B., Ariztegui, D., 2020, Weak influence of paleoenvironmental conditions on the subsurface biosphere of Lake Ohrid over the last 515 ka: Microorganisms, 8(11), 1736, https:// doi.org/10.3390/microorganisms 8111736

Tian, J., Wang, Y., Dong, X., 2010, Methanoculleus hydrogenitrophicus sp. Nov., a methanogenic archaeon isolated from wetland soil: International Journal of Systematic and Evolutionary Microbiology, 60(9), 2165-2169, https:// doi.org/10.1099/ijs.0.019273-0

Torti, A., Lever, M.A., Jørgensen, B.B., 2015, Origin, dynamics, and implications of extracellular DNA pools in marine sediments: Marine Genomics, 24, 185-196, https://doi.org/10.1016/j.margen.2015.08.007
EPA (US Environmental Protection Agency), 2001, EPA-821-R-01-010, Method 200.7: Trace elements in water, solids, and biosolids by inductively coupled plasma-atomic emission spectrometry, Revision 5.0: Washington, D.C., US Environmental Protection Agency, Office of Science and Technology, $68 \mathrm{pp}$.

Vuillemin, A., Ariztegui, D., Horn, F., Kallmeyer, J., Orsi, W.D., Team, P.S., 2018, Microbial community composition along a 50000 -year lacustrine sediment sequence: FEMS Microbiology Ecology, 94(4), fiy029, https:// doi.org/10.1093/femsec/fiy029

Vuillemin, A., Horn, F., Alawi, M., Henny, C., Wagner, D., Crowe, S. A., Kallmeyer, J., 2017, Preservation and significance of extracellular DNA in ferruginous sediments from Lake Towuti, Indonesia: Frontiers in Microbiology, 8, 1440, https://doi.org/10.3389/fmicb.2017.01440

Wainø, M., Tindall, B., Ingvorsen, K., 2000, Halorhabdus utahensis gen. Nov., sp. Nov., an aerobic, extremely halophilic member of the Archaea from Great Salt lake, Utah: International Journal of Systematic and Evolutionary Microbiology, 50(1), 183-190, https://doi.org/10.1099/00207713-50-1-183

Wangen, M., 2001, A quantitative comparison of some mechanisms generating overpressure in sedimentary basins: Tectonophysics, 334(3-4), 211-234, https://doi.org/10.1016/S0040-1951(01)00064-6

Whitman, W.B., Bowen, T.L., Boone, D.R., 2006, The methanogenic bacteria: Prokaryotes, 3(9), 165-207.

Wickham, H., 2016, ggplot2: Elegant Graphics for Data Analysis: New York, Springer-Verlag, $260 \mathrm{pp}$.

Yang, Y., Li, N., Wang, W., Li, B., Xie, S., Liu, Y., 2017, Vertical profiles of sediment methanogenic potential and communities in two plateau freshwater lakes: Biogeosciences, 14(2), 341-351, https://doi.org/10.5194/bg-14-341-2017

Manuscript received: may 24, 2021

Corrected manuscript received: october 18, 2021

Manuscript accepted: october 20, 2021 